Kargın, T. ve Karataş, A. (2021). Sınıf öğretmenlerinin gözünden küresel salgın sürecinde uzaktan eğitim aracılığıyla ilk okuma yazma öğretimi. Ana Dili Eğitimi Dergisi, 9(4), 1264-1284.

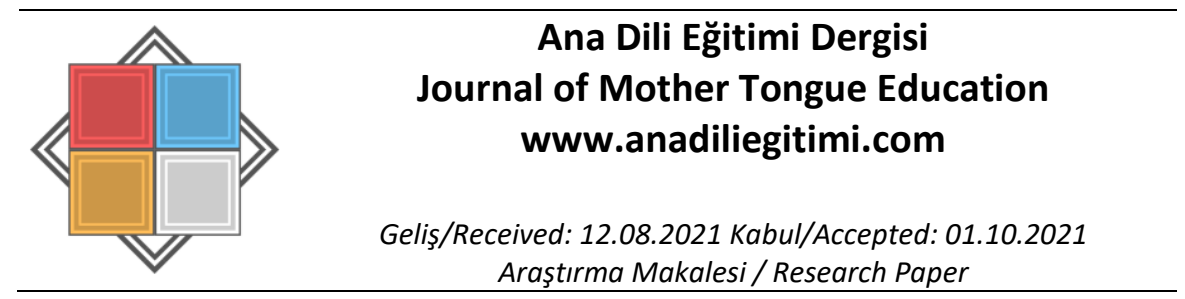

\title{
Sınıf Öğretmenlerinin Gözünden Küresel Salgın Sürecinde Uzaktan Eğitim Aracılığıyla İlk Okuma Yazma Öğretimi
}

\author{
Tolga KARGIN* \\ Arda KARATAŞ**
}

Öz

Bu çalışmada, birinci sınıf öğretmenlerinin küresel salgın sürecinde uzaktan eğitim aracılı̆̆ıyla ilk okuma yazma öğretimini nasıl gerçekleştirdiklerinin ve uzaktan eğitim sürecinde ne tür sorunlar yaşadıklarının tespit edilmesi amaçlanmıştır. Çalışmada, nitel araştırma yöntemlerinden durum çalışması deseni benimsenmiştir. Her bölgeden iki öğretmen olmak üzere 14 öğretmen ile yarı yapılandırılmış görüşmeler gerçekleştirilmiş ve veriler içerik analizine tabi tutulmuştur. Analizler neticesinde, elektrik ve internet altyapısı ile ilgili sorunlar, uzaktan eğitimde günlük ders saatinin fazla olması, ilk okuma yazma öğretiminde seslerin çıkarılmasına ve yazımına ilişkin sorunlar, velilerin bilinçsiz davranışları, ailelerin maddi yetersizliklerinden kaynaklı sorunlar, EBA platformunun içeriğindeki yetersizlikler ve öğretmenlerin hizmet içi eğitim almamış olmaları en sık ifade edilen sorunlar olmuştur. Uzaktan eğitim aracılı̆̆ıyla ilk okuma yazma öğretimi gerçekleştirirken öğretmenlerin yüz yüze eğitim sürecindeki ders planlarını ve materyallerini kullanmaya devam ettikleri, bunun yanında videoları ve web platformlarını aktif olarak kullandıkları, oyun temelli bir öğretim gerçekleştirdikleri ve uzaktan eğitim sürecinde velilerin desteğini alarak ilerledikleri sonuçlarına ulaşıımıştır.

Anahtar Kelimeler: Uzaktan eğitim, ilk okuma yazma, sınıf öğretmeni, birinci sınıf, küresel salgın

\section{Teaching Literacy via Distance Education in the Pandemic Through the Eyes of Primary School Teachers}

\begin{abstract}
In this study, it is aimed to determine how first grade teachers taught how to read and write via distance education during the pandemic and what kind of issues they encountered in the distance education process. In the study, the case study method, which is one of the qualitative research methods, was adopted. Semi-structured interviews were conducted with 14 teachers, two from each region, and the collected data were analyzed by using the content analysis method. Accordingly, the problems related to electricity and internet infrastructure, excessive daily lesson hours in distance education, issues related to pronunciation and writing of some letters, unconscious behaviors of parents, issues caused by financial inadequacies of families, inadequacies in the content of the EBA platform, and the fact that teachers did not receive in-service training were the most frequently encountered problems expressed by the teachers. It has been found that while teaching how to read and write via distance education, the teachers continued to use the lesson plans and the materials that they used in the face-to-face education process, besides, they actively used videos and web-based platforms, they adopted a game-based education model, and they progressed with the support of the parents in the distance education process.
\end{abstract}

Keywords: Distance education, literacy, primary school teacher, first grade, pandemic

\footnotetext{
* Dr. Öğr. Üyesi, Uşak Üniversitesi, Eğitim Fakültesi, Temel Eğitim Bölümü, Uşak, tolga.kargin@usak.edu.tr, ORCID: orcid.org/0000-0003-2380-2383

** Öğretmen, Millî Eğitim Bakanlığı, İstanbul, ardakrtss@gmail.com, ORCID: orcid.org/0000-0001-5171-1783
} 


\section{Giriş}

Insanoğlu var olduğundan itibaren yeni bilgiye ulaşmak için çaba içerisinde olmuştur. Bu çaba ile birlikte eğitim kavramı da ortaya çıkmıştır. Eğitim, Türk Dil Kurumu'na göre (2021) "genç nesillerin toplum içerisinde yerlerini almaları için gerekli bilgi, beceri ve anlayışları elde etmelerine, kişiliklerini geliştirmelerine okul içinde veya dışında, doğrudan veya dolaylı yardım etme, terbiye" olarak tanımlanmaktadır. Eğitimin tanımının TDK tarafından yapılan bu tanımdan daha da kapsamlı yapılması gerekmektedir. Öğretimi de içerisine alan bu kapsam düşünüldüğünde eğitimin; planlı ya da tesadüfi sistemlerle hayat boyu devam eden, kişisel gelişim, okul, aile, çevre ve materyaller gibi uyarıcı etkenler vasıtasıyla bireylerin idealler oluşturmasına ve bu ideallere ulaşılmasında değer yargıları oluşturulmasına imkân veren bir süreç olarak tanımlanması daha doğru olacaktır (Akyüz, 1982; Bilhan, 1991; Ergün, 2009). Kısaca bireylerin kendi istekleriyle yaşantı yoluyla davranışlarında meydana getirdiği değişim süreci olarak adlandırılabilir (Ertürk, 1984). Bireylerin hayatı boyunca devam ettiği kabul edilen eğitim sürecinin daha verimli olabilmesi için çeşitli eğitim yöntemlerinin doğru bir şekilde kullanılması gerekmektedir.

Günümüzde yaşanan teknolojik gelişmeler ile birlikte eğitim ile ilgili yapılan çalışmalar da artmış ve yeni yöntem ve uygulamalar kullanılmaya başlamıştır (Güneş, 2000, s. 22; Kırık, 2014). Eğitimde daha önce kullanılan geleneksel ders ortamları, ders materyalleri ve öğretim yöntem ve teknikleri yerini teknolojik gelişmelerle birlikte yeni ders ortamlarına (e-öğrenme platformları vb.), ders materyallerine (web 2.0 araçları vb.) ve yeni yöntem ve tekniklere bırakmıştır (Demir, 2014; s.205). Günümüz çocuklarının da dijital teknolojiye yatkın olması, bu tür teknolojilerin eğitime ve eğitim ortamlarına dâhil edilmesini zorunluluk haline getirmiştir. Eğitim programlarının genelinde kullanılan yapılandırmacı öğrenme kuramına göre öğrenen çocuğun kendisi olacağından çocuk merkeze alınarak onun ilgi ve yetenekleri doğrultusunda içerik zenginliğini genişletmek zorunluluk haline gelmiştir (Sönmez, 2017). E-öğrenme platformlarının ve eğitim teknolojilerinin artık daha ulaşılabilir olması uzaktan eğitim kavramını da beraberinde getirmiştir.

\section{Uzaktan Eğitim}

Illk olarak 1892 yılında Wisconsin Üniversitesi kataloğunda uzaktan eğitim (Distance Education) terimi kullanılmıştır. Aynı üniversitenin yöneticisi William Lighty ise 1906 yılında bir yazısında bu terimi kullanmıştır (Sirem ve Baş, 2020). Uzaktan eğitim tarihine bakıldığında aslında bu yöntemin geçmiş yıllardan itibaren mektup, radyo, kitap, gazete gibi çeşitli araçlarla yürütülmeye çalışıldığı görülmektedir. Son yıllarda teknolojik imkanların artmasıyla birlikte uzaktan eğitim ortamlarının çeşitlendirilmesi yeni bir kavram gibi algılanmasına neden olmaktadır (Clark, 2020; Ruksasuk, 1999). Ülkemizde de uzaktan eğitim çalışmaları 1924 yılında Dewey tarafından hazırlanan "Öğretmen Eğitim Raporu" ile gündeme gelmiş ve 1950 yılında mektup ile çalışmalar başlatılmıştır (Iş̧man, 2011). 1960'ı yıllardan itibaren ise bu terim tüm dünyada geniş bir kullanım alanına sahip olmuştur (Adıyaman, 2002; Thompson ve diğerleri, 1996).

Uzaktan eğitim tanımlanırken geleneksel olmayan eğitim ve okul dışında gerçekleşen eğitim gibi tanımlamalar kullanılmaktadır (Kaya, 1996). Ancak bu tanımlar günümüzde uzaktan eğitim kavramını tam olarak karşılamamaktadır. Geçmişten günümüze kadar birçok alanda kullanılan uzaktan eğitim; mekân ve zaman kıııtlaması olmadan (Adıyaman, 2002; Akdemir, 2011; Düzakın ve Yalçınkaya, 2008; Ekici, 2003; Karakuş ve diğerleri, 2020; Newby ve diğerleri, 2006; Odabaş, 2003), özel ders tasarımları ve öğretim yöntemlerinin kullanıldığı (Alkan, 1987; Holmberg, 1989; Moore ve Kearsley, 2005; Özbay, 2015; Uşun, 2006), elektronik olan ya da olmayan sistemler üzerinden (Altıparmak, 2011; Kırık, 2014) eş zamanlı ya da eş zamanlı olmayan düzenlemeler aracılığı ile (Kaçan ve Gelen, 2020; Simonso ve diğerleri, 2003) eğitimi daha geniş kitlelere ulaştırarak eğitimde fırsat eşitliğini sağlamayı amaçlayan (Yalın, 2009) sistemli ve planlı bir eğitim modeli (Göktaş ve diğerleri, 2008; Moore ve Kearsley, 2005) olarak tanımlanabilir.

Simonso ve diğerlerine $(2003$, s.125) göre uzaktan eğitim tanımı dört unsurdan meydana gelmiştir. Bu unsurlar, informal ve kendiliğinden (geleneksel) eğitimden farklı olarak bir kurum tarafından yürütülen formal bir eğitim olması, öğretici ve öğrenenlerin hem zaman hem de mekân boyutuyla birbirinden ayrı olması, iletişim teknolojilerinin yardımcı araçlar olarak kullanılması, 
öğrenen, öğretici, kaynak ve içerikler arasında uyum sağlanarak öğretim tasarımlarının etkin olması şeklindedir. Tanımlar dikkate alındığında uzaktan eğitimin, günümüz şartlarında önemli bir yeri olduğu kabul edilmektedir. Uzaktan eğitimin geniş kitlelere hitap edebilmesi, zaman ve mekân serbestliği ile öğrenme ortamlarının zenginleştirilebilmesi, bireylerin öğrenme yöntemlerine göre içeriklerin düzenlenebilmesi (Akdemir, 2011; Arat ve Bakan, 2014; İşman, 2011; Uluğ, 1994), ekonomik olması ve erişilebilir olması (Murphy ve Beggs, 2003; Traxler, 2018) gibi faydaları düşünüldüğünde uzaktan eğitimin geleneksel sisteme göre çeşitli avantajlarının olduğu görülebilmektedir.

\section{Küresel Salgın Sürecinde Uzaktan Eğitim}

Uzaktan eğitimin sunduğu çeşitli avantajlar 1800'lü yıllardan itibaren bilinmesine rağmen 2019 yılının sonlarına doğru başlayan Koronavirüs (Covid-19) salgını, uzaktan eğitimin tüm dünyanın gündemine oturmasını sağlamıştır (Eken ve diğerleri, 2020). Dünya Sağlık Örgütü tarafından küresel salgın olarak adlandırılan Koronavirüs salgını, dünya genelinde birçok faaliyetin durmasına veya askıya alınmasına neden olmuştur (WHO, 2020). Bu aksamalar eğitim alanında da kendisini hissettirmiştir. Tüm dünyada olduğu gibi ülkemizde de 2020 yılında tüm eğitim kademelerinde yüz yüze eğitime ara verilmiştir. Salgının seyrine göre zaman zaman tekrar yüz yüze eğitime dönülmüş zaman zaman da tekrar ara verilmiştir (Bozkurt, 2020a; Bozkurt ve diğerleri, 2020; Bozkurt ve Sharma, 2020; Hodges ve diğerleri, 2020). Küresel salgın sürecinde ülkeler eğitimin aksamaması amacıyla geleneksel modelden uzaktan eğitim modeline geçilmesi çalışmalarına hız vermişlerdir. Dünyada yer alan diğer ülkeler gibi ülkemizde de bu süreçte eğitimin kesintiye uğramaması adına uzaktan eğitimle ilgili çalışmalar hız kazanmış ve yüz yüze eğitime ara verilen dönemlerde okul öncesinden liseye kadar eğitim gören yaklaşık 16 milyon öğrenci uzaktan eğitim ile öğrenim görmeye başlamıştır (UNESCO, 2020).

Bütün ülke genelinde zorunlu bir şekilde uzaktan eğitime geçilmiş olması bazı sorunları da beraberinde getirmiştir. Her ne kadar süreç içerisinde sistem ve altyapı hazırlanıp karşılaşılan sorunlar giderilmeye çalışılsa da uzaktan eğitim ile ilgili sorunlar halen gözlemlenmeye devam etmektedir. Alan yazında bu sorunların tespit edilmesi ve öneriler sunulması amacıyla gerçekleştirilen çeşitli çalışmalara rastlanmaktadır. Öğretmen adayları ile yapılan çalışmalara bakıldığında öğretmen adaylarının uzaktan eğitim konusunda isteksiz oldukları ve kendilerini uzaktan eğitim açısından yeterli görmedikleri bulgusu ön plana çıkmakta (Karatepe ve diğerleri, 2020), uzaktan eğitimden ziyade yüz yüze eğitim için istekli oldukları sonucuna ulaşılmaktadır (Karakuş ve diğerleri, 2020).

Uzaktan eğitim sürecine ilişkin öğretmenlerle küresel salgının başladığı dönemlerde yapılan çalışmalara bakıldığında öğretmenlerin kendilerini uzaktan eğitim konusunda yetersiz hissetmelerinden dolayı kaygılı oldukları görülmektedir (Bakioğlu ve Çevik, 2020). Yapılan daha güncel çalışmalarda ise ortaokul öğretmenlerinin uzaktan eğitim modelini benimsedikleri ve bu yeni teknolojiyi kabul ettiklerini vurgulanmaktadır (Canpolat ve Yıldırım, 2021). Ancak öğretmenlerin çeşitli çalışmalarda öğrencilerin derse ilgisiz olduklarını, derslere katılımın düşük olduğunu ve fırsat eşitsizliklerinden kaynaklı öğrenciler arasında sıkıntılar yaşandığını vurguladıkları (Bayburtlu, 2020) görülmektedir. Bunların yanı sıra altyapı yetersizliği ve velilerin süreç içerisine derslere gereğinden fazla müdahil olmaları öğretmenlerin sürece ilişkin dikkat çektikleri diğer sorunlar olmuştur (Kavuk ve Demirtaş, 2021). Yapılan bir diğer çalışmada ise aslında ilkokul düzeyinde öğrenim gören öğrencilerin de uzaktan eğitim ile birlikte sorumluluk alabildikleri ancak öğrencilerin derslere iyi motive edilmesi ve velilerin süreç içerisinde aktif olarak rol oynaması gerektiğini savunmuştur (Bozkurt, 2020b).

Yapılan alan yazın taraması sonucunda salgın döneminden itibaren uzaktan eğitimin sorunları ve bu sorunlara çözüm önerileri üretebilmek amacıyla yapılmış çalışmalar olduğu görülmektedir. Ancak bu çalışmaların genellikle üniversite, lise ve ortaokul düzeyine yönelik öğretmen adaylarını, öğretmenleri ve öğrencileri hedef alan çalışmalar olduğu görülmektedir. Illkokul düzeyinde yapılmış az sayıda çalışmaya rastlanılmıştır. İncelenen bu çalışmaların da genellikle ilkokul birinci sınıf öğretmen ve öğrencilerinin yaşadığı sorunlardan ziyade daha üst sınıflara ilişkin çalışmalar olduğu tespit edilmiştir (Altınpulluk, 2021; Balaman ve Hanbay Tiryaki, 2021; Canpolat ve Yıldırım, 2021; Gökbulut, 2021; Karaca ve diğerleri, 2021; Özer ve Turan, 2021; Sirem ve Baş, 2020). 


\section{Uzaktan Eğitim Aracılığıyla Illk Okuma Yazma}

Çocukların iyi birer okur olarak yetişmesi isteniyorsa temel okuma ve yazma becerilerinin geliştirilmesi gerekmektedir. Illk okuma yazma eğitimi; okuryazarlık düzeyine gelmek için gösterilen çalışmaların tümü olarak kabul edilmektedir (Yeleğen, 1977). Bu tanımdan daha geniş kapsamlı olarak ilk okuma yazma; çocukların okuduğunu anlayabilen, okuduklarını yeni durumlara uyarlayabilen (Ünüvar, 2001), duygu ve düşüncelerini yazılı olarak ifade edebilen ve okuma ve yazma için güçlü istek duyabilen birer birey olmalarını sağlama süreci olarak da tanımlanabilir. İlk okuma yazma eğitiminin genel amacı, öğrencilere yaşamları boyunca ihtiyaçları olan okuma yazma becerilerinin kazandırılarak okuryazarlık düzeyine ulaşmalarını sağlayabilmektir. Illk okuma yazma öğretiminde sınıf öğretmeninin rolü büyüktür (Karaman ve Yurduseven, 2008). Ancak günümüzde sınıf öğretmenlerinin rolünün yanında ilk okuma yazma eğitiminde teknoloji kullanımının da önemi göz ardı edilemez. Eğitim teknolojileri aracılığı ile okuma yazma sürecinde kullanılan materyalleri zenginleştirmek ve daha donanımlı bir öğrenme ortamı hazırlamak mümkündür. Özellikle halen etkisi devam eden küresel salgın sürecinde uzaktan eğitime geçilerek çeşitli eğitim platformları aktif olarak kullanılmaya başlanmıştır. Devlet okullarındaki öğrenciler ağırlıklı olarak Eğitim Bilişim Ağı (EBA) platformundan ve öğretmenlerin tavsiye ettiği çeşitli web tabanlı platformlardan yararlanırken, bazı özel okullarda geliştirilen yapay zekâ uygulamaları da bu süreçte etkin bir şekilde kullanılmıştır (Baran ve Sadık, 2021). Bu durum eğitim teknolojilerinin günümüzde ne denli önem taşıdığını bir kez daha ortaya koymuştur.

ilkokul birinci sınıf, henüz altı yaşını yeni doldurmuş çocukların okula ve formal eğitime adapte olmaları ve okuma yazma öğrenmeleri gereken bir dönem olup kritik bir öneme sahiptir. Birinci sınıf öğrencilerinin ve öğretmenlerinin küresel salgın sürecinde bu kritik eğitim dönemini uzaktan eğitim ile geçirmiş olmaları sebebiyle nasıl bir eğitim yılı geçirdiklerinin araştırılması, karşılaştıkları sorunların tespit edilmesi ve çözüm önerileri sunulması önem arz etmektedir. Alan yazın tarandığında küresel salgın sürecinde eğitimde yaşanan aksaklıklara yönelik gerek orta öğretim (Canpolat ve Yıldırım, 2021) gerekse yüksek öğretim düzeyinde (Karatepe ve diğerleri, 2020; Özer ve Turan, 2021) çeşitli çalışmaların olduğu ancak ilkokul düzeyinde (Erbaş, 2021) çok sınırlı sayıda çalışmanın olduğu görülmektedir. Bu çalışma küresel salgın sürecinde uzaktan eğitim ile ilk okuma yazma öğretiminin nasıl ilerletildiğini ortaya koymak adına önemli olan ve zamanında yapılan bir çalışmadır. Bu çalışmanın gelecekte zorunlu veya gönüllü olarak uzaktan eğitime geçilmesinin tercih edildiği durumlarda eğitim sürecinin planlanmasına katkı sağlayacağı düşünülmektedir.

Bu çalışmada aşağıdaki araştırma sorularına cevap aranmıştır:

1. illkokul birinci sınıf öğretmenlerinin uzaktan eğitim süresince en sık karşılaştıkları sorunlar nelerdir?

2. Küresel salgın sürecinde uzaktan eğitim aracılığıyla ilk okuma yazma öğretimi nasıl gerçekleştirilmiştir?

\section{Araştırmanın Modeli}

\section{Yöntem}

Bu araştırmada nitel araştırma yöntemlerinden durum çalışması deseni benimsenmiştir. Durum çalışmaları, sınırlı bir sistemin nasıl işlediği hakkında derinlemesine inceleme yapılan bir yaklaşımdır (Chmiliar, 2010; Merriam, 2009; Punch, 2014). Durum çalışmalarında araştırılacak olan durumun iyi tanımlanması ve sınırlarının net olarak çizilmesi esastır. Bu çalışmada da küresel salgın döneminde zorunlu olarak kullanılmaya başlanan uzaktan eğitim modelinde birinci sınıf öğretmenlerinin ilk okuma yazma öğretimi ile ilgili düşünceleri detaylı bir şekilde incelenmek istendiğinden durum çalışması tercih edilmiştir. Bu çalışmada, ilkokul birinci sınıf öğretmenlerinin uzaktan eğitim aracılığıyla ilk okuma yazma öğretimi sürecine ilişkin görüşlerine başvurulmuş ve tüm süreç öğretmenlerin görüşleri çerçevesinde kapsamlı bir şekilde değerlendirilmiştir.

\section{Çalışma Grubu}

Bu araştırma ilkokul birinci sınıf düzeyinde görev yapan sınıf öğretmenlerinden oluşan çalışma grubu ile gerçekleştirilmiştir. Çalışma grubu oluşturulurken çalışmanın Türkiye'deki genel durum hakkında bir fikir vermesi için amaçlı örneklem türlerinden maksimum çeşitlilik örneklemi ilkeleri 
benimsenmiştir. Bu örneklemin kullanılma amacı, küçük bir örneklem grubu ile probleme taraf olabilecek bireylerin çeşitliliğini yüksek düzeyde yansıtmaktır (Yıldırım ve Şimşek, 2018).

Tablo 1.

Katılımcıların Demografik Bilgileri

\begin{tabular}{llll}
\hline Katılımcı Bilgisi & Cinsiyeti & Görev Yılı & Görev Yaptığı Bölge \\
\hline Ö.1 & Kadın & 15 & Marmara Bölgesi \\
Ö.2 & Erkek & 21 & Marmara Bölgesi \\
Ö.3 & Kadın & 20 & Ege Bölgesi \\
Ö.4 & Erkek & 16 & Ege Bölgesi \\
Ö.5 & Kadın & 22 & Akdeniz Bölgesi \\
Ö.6 & Erkek & 1 & Akdeniz Bölgesi \\
Ö.7 & Kadın & 16 & İç Anadolu Bölgesi \\
Ö.8 & Erkek & 7 & İç Anadolu Bölgesi \\
Ö.9 & Kadın & 18 & Karadeniz Bölgesi \\
Ö.10 & Erkek & 6 & Karadeniz Bölgesi \\
Ö.11 & Kadın & 2 & Doğu Anadolu Bölgesi \\
Ö.12 & Erkek & 5 & Doğu Anadolu Bölgesi \\
Ö.13 & Kadın & 1 & Güney Doğu Anadolu Bölgesi \\
Ö.14 & Erkek & 1 & Güney Doğu Anadolu Bölgesi \\
\hline
\end{tabular}

Tablo 1'de görüldüğü gibi, çalışma grubu ülkemizin tüm bölgelerinden iki sınıf öğretmeni olmak üzere gönüllü 14 öğretmenden oluşmaktadır. Erkek ve kadın öğretmenlerin gerek günlük yaşantılarında gerekse eğitim verme sürecinde teknoloji kullanımlarının farklııı gösterebildiği (Gebhardt ve diğerleri, 2019) dikkate alınarak her bölgeden bir kadın ve bir erkek öğretmen örnekleme dâhil edilmiştir. Ayrıca daha genç öğretmenler ile daha olgun öğretmenlerin ya da göreve yeni başlamış öğretmenler ile daha deneyimli öğretmenlerin teknoloji kullanımları arasında da farklılık olabileceği göz önünde bulundurularak çalışmaya dâhil edilen öğretmenlerin meslekteki kıdem durumlarının da mümkün olduğunca farklı olmasına dikkat edilmiştir. Tablo 1 'de görüldüğü gibi öğretmenlerin yedi tanesi 0-10 yıl mesleki deneyime, beş tanesi 11-20 yıl mesleki deneyime, iki tanesi de 20 yılın üzerinde mesleki deneyime sahiptir.

\section{Veri Toplama Araçları}

Araştırmanın verileri yarı yapılandırılmış görüşmelerle elde edilmiştir. Toplam sekiz sorudan oluşmakta olan görüşme formu gerçekleştirilen alan yazın taramasının ardından araştırmacılar tarafından hazırlanmıştır. Elde edilen sorular ile ilgili iki alan uzmanından görüş alınmıştır. Alan uzmanlarının vermiş olduğu dönütler doğrultusunda görüşme soruları yeniden düzenlenmiştir. Soruların açık ve anlaşılır olduğunu denetlemek amacıyla iki sınıf öğretmeniyle pilot görüşmeler gerçekleştirilmiştir. Pilot görüşmeler neticesinde görüşme formunda yer alan soruların araştırmaya katılacak öğretmenler tarafından anlaşılabilir olduğu kanaatine varılmıştır.

\section{Verilerin Toplanması}

Koronavirüs küresel salgını nedeniyle katılımcılarla yüz yüze görüşme gerçekleştirilememiştir. Bunun yerine katılımcılarla Google Meet platformu üzerinden görüntülü görüşme yapılmış ve görüşmeler kayıt altına alınmıştır. Görüşmeler 30 ila 40 dakika arasında sürmüştür.

\section{Verilerin Analizi}

Araştırmanın verileri içerik analizi yöntemi kullanılarak analiz edilmiş, oluşturulan kodlar verinin içerisinden türetilmiştir (Merriam, 2009). Birbiriyle yakınlık gösteren kodlar bir araya getirilerek temalar oluşturulmuştur. Nitel çalışmalarda analizler sonucunda oluşturulan temaların çalışmanın alt problemine cevap niteliğinde olması gerekmektedir (Merriam, 2009). Bu çalışmada da çalışmanın her bir alt problemi birkaç tema ile cevaplanmıştır. 


\section{Geçerlik ve Güvenirlik Çalışmaları}

Veri toplama süreci öncesinde görüşme formu hazırlanırken, yukarıda da belirtildiği gibi, iki alan uzmanından görüş alınmış, iki sınıf öğretmeni ile de pilot çalışma yapılarak kapsam geçerliği sağlanmıştır. İnandırıcılık ilkesini yerine getirmek adına görüşmeler yapıldıktan sonra katılımcılara kendi görüşlerinin yer aldığı formlar gönderilmiş ve bilgilerin kendi ifade etmek istediklerini tam olarak yansıtıp yansıtmadığı ile ilgili dönütler alınmıştır. Katılımcıların tamamından yazıya dökülmüş görüşlerin kendi görüşlerini yansıttığı cevabı alınmıştır. Bu çalışmada aktarılabilirlik ilkesi dikkate alınarak çalışmanın katılımcıları ve çalışmanın içeriği ve kapsamı ile alakalı detaylı bilgilere yer verilmiş, çalışmanın bulguları katılımcıların kendi ifadeleri ile sunulmuştur. Güvenilebilirlik ilkesine uygun olarak çalışmanın veri toplama ve veri analizi süreci detaylı olarak aktarımış, verilerin analizi sürecinde iki farklı araştırmacı birbirinden bağımsız olarak kodlama yapmış ve yapılan analizler karşılaştııılarak görüş birliğine varılması önemsenmiştir. Onaylanabilirlik ilkesini yerine getirmek adına katılımcılarla gerçekleştirilen görüşmelerin video kayıtları araştırmacının ofisinde kilitli dolapta saklanmaktadır.

\section{Araştırma ve Yayın Etiği}

Bu çalışmada "Yükseköğretim Kurumları Bilimsel Araştırma ve Yayın Etiği Yönergesi" kapsamında uyulması belirtilen tüm kurallara uyulmuştur. Yönergenin ikinci bölümü olan "Bilimsel Araştırma ve Yayın Etiğine Aykırı Eylemler" başlığı altında belirtilen eylemlerden hiçbiri gerçekleştirilmemiştir.

\section{Etik Kurul İzni} Etiği Kurulu

Kurul adı= Uşak Üniversitesi Rektörlüğü Sosyal ve Beşerî Bilimler Bilimsel Araştırma ve Yayın

Karar tarihi $=10.06 .2021$

Belge sayı numarası $=2021-129$ sayılı karar

\section{Bulgular}

Katılımcılarla gerçekleştirilen yarı yapılandırılmış görüşmelerden elde edilen veriler içerik analizine tabi tutularak analiz edilmiş, birbirine yakın kodlar bir araya getirilerek çalışmanın alt problemlerine cevap verecek şekilde temalar oluşturulmuştur. Her bir alt probleme ilişkin bulgular ayrı başlıklar halinde aşağıda sunulmuştur.

\section{İlkokul Birinci Sınıf Öğretmenlerinin Uzaktan Eğitim Sürecinde Karşılaştıkları Sorunlar}

Bu çalışmada öncelikle ilkokul birinci sınıf öğretmenlerinin uzaktan eğitim sürecinde yaşadıkları sorunların tespit edilmesi amaçlanmıştır. "illkokul birinci sınıf öğretmenlerinin uzaktan eğitim süresince en sık karşılaştıkları sorunlar nelerdir?" şeklinde tanımlanan birinci alt probleme ilişkin bulgular dokuz başlık altında Tablo 2'de sunulmuştur.

Tablo 2.

Ilkokul Birinci Sınıf Öğretmenlerinin Uzaktan Eğitim Sürecinde Karşılaştıkları Sorunlar

\begin{tabular}{|c|c|c|c|}
\hline Tema & $f$ & $n$ & Görüş Belirten Katılımcılar \\
\hline Altyapı Sorunları & 11 & 14 & $\begin{array}{l}\text { Ö.1, Ö.2, Ö.3, Ö.4, Ö.5, Ö.8, Ö.9, Ö.10, Ö.11, } \\
\text { Ö.12, Ö.13 }\end{array}$ \\
\hline $\begin{array}{l}\text { Günlük Ders Saati Sayısının Fazla } \\
\text { Olması }\end{array}$ & 10 & 14 & $\begin{array}{l}\text { Ö.2, Ö.3, Ö.4, Ö.5, Ö.6, Ö.7, Ö.9, Ö.11, Ö.13, } \\
\text { Ö.14 }\end{array}$ \\
\hline $\begin{array}{l}\text { Velilerin Uzaktan Eğitim } \\
\text { Sürecindeki Bilinçsiz Davranışları }\end{array}$ & 10 & 14 & $\begin{array}{l}\text { Ö.1, Ö.2, Ö.3, Ö.5, Ö.6, Ö.8, Ö.11, Ö.12, } \\
\text { Ö.13, Ö.14 }\end{array}$ \\
\hline $\begin{array}{l}\text { Ailelerin Maddi Yetersizliklerine } \\
\text { Bağlı Sorunlar } \\
\text { İlk Okuma Yazma Öğretiminde }\end{array}$ & 9 & 14 & Ö.1, Ö.4, Ö.6, Ö.7, Ö.8, Ö.9, Ö.10, Ö.11, Ö.14 \\
\hline $\begin{array}{l}\text { Seslerin Çıkarılmasına ve Yazım } \\
\text { Yönlerine İlişkin Sorunlar }\end{array}$ & 9 & 14 & Ö.1, Ö.2, Ö.3, Ö.4, Ö.7, Ö.8, Ö.9, Ö.13, Ö.14 \\
\hline
\end{tabular}


Sınıf Öğretmenlerinin Gözünden Küresel Salgın Sürecinde Uzaktan Eğitim Aracilığıyla Illk Okuma Yazma öğretimi

\begin{tabular}{llll}
\hline EBA Platformunun Yetersiz Olması & 8 & 14 & Ö.5, Ö.6, Ö.7, Ö.8, Ö.10, Ö.11, Ö.12, Ö.14 \\
Hizmet İçi Eğitim Eksikliği & 6 & 14 & Ö.4, Ö.5, Ö.6, Ö.7, Ö.9, Ö.11 \\
$\begin{array}{l}\text { Öğrencilerin Uyum Sorunları } \\
\begin{array}{l}\text { Öğretmenin Üzerinde Baskı } \\
\text { Hissetmesi }\end{array}\end{array}$ & 5 & 14 & Ö.5, Ö.7, Ö.8, Ö.9, Ö.10 \\
\hline
\end{tabular}

\section{Altyapı Sorunları}

Çalışmaya katılan öğretmenlerin tamamına yakını öğrencilerin altyapı yetersizliği sebebiyle uzaktan eğitim platformuna erişim sorunu yaşadığını belirtmişlerdir. Öğretmen görüşlerinden bazıları şu şekildedir:

Elektrik kesintisi çok oluyor. Mesela burada bir anda elektrik kesiliyor. Ben tek başıma kalıyorum. Hiç kimse yok. Biri arıyor, biri katılamıyor, ders yarım kalıyor. Bunlar da hep verimi düşürüyor (Ö.11, 26.05.2021).

Eğer 20 kişilik sınıftan beş - altı öğrenci derse katılabiliyorsa biz buraya okul ortamı diyemeyiz. Öncelikle internete erişimi olmayan öğrencimizin kalmaması gerekiyor. Bunun yanında internet alt yapısının da iyileştirilmesi gerekiyor. Bir derste hem ben hem de öğrencilerim internet hızından kaynaklı olarak dört - beş defa donma ve takılma yaşayabiliyoruz (Ö.12, 24.05.2021).

Büyük kızım lisede, küçük kızım ilkokulda, hanım öğretmen, herkes canlı derste. Ben bile interneti zar zor kullanabildim. Yani yeni eve taşındım, üç artı bir. Herkes ayrı bir odada ama internet alt yapısı taşımıyor yani. Yani altyapımız uygun değil ki düşünün biz öğretmeniz gelirimiz falan var (Ö.1, 14.06.2021).

Katılımcıların görüşlerinden de anlaşılacağı gibi uzaktan eğitim sürecinde öğrenciler yaşadıkları bölgelere göre elektrik ve internet altyapısının yetersizliğinden kaynaklı sorunlar yaşamışlardır. Köylerde sık sık yaşanan elektrik kesintileri uzaktan eğitim sürecinde aksamalara sebep olmuştur. Yeterli ekonomik gücü olmadığı için internet erişimi kısıtlı olanlar ya da hiç olmayanlar derslere katılamamış, internet erişiminde sorun yaşamayanlar da evlerde birkaç kişinin aynı anda canlı derslere katılması gerektiği için altyapı yetersizliğinden kaynaklı kesintiler ve ekran donmaları yaşamışlardır. Katılımcıların vurguladığı gibi yaşanan altyapı sorunları uzaktan eğitim sürecindeki verimi de düşürmüştür.

\section{Günlük Ders Saati Sayısının Fazla Olması}

Katılımcıların dikkat çektiği diğer bir önemli sorun ise birinci sınıf öğrencilerini uzaktan eğitim sürecinde her gün altı ders saati ekran başında tutmak olmuştur. Öğretmen görüşlerinden bazıları şu şekildedir:

Birinci sınıf öğrencisi biliyorsunuz 72 aylık, yani çok küçük çocukların yaşları. Onlar için uzun yani (ders saati). Şu an bile siz otururken zorlanıyorsunuz, ben otururken zorlanıyorum. Onlar uzun süre oturarak devam ettiler. Bu yönden sıkıntı yaşadık. Yani haftada 30 ders saatinin uzun olduğunu ben düşünüyorum (Ö.4, 27.05.2021).

Öğrencileri altı ders boyunca ekran karşısında tutmak inanılmaz zor. Zaten sınıfta tutmak bile zor. Altı ders bana göre fazla. En çok dördüncü derse kadar idare ediyordum. Daha sonrası çok verimsiz geçiyordu. Ekran başında altı ders boyunca çok sıkıldılar (Ö.5, 22.05.2021).

İlk başlarda altı ders yapıyordum ama sonraları azaltmak zorunda kaldım. Mesela şimdi dört ders yapıyorum. Yani çocuklar artık sıkıldı. Ekran karşısında oturmak istemiyor. Malum köy yeri olduğu için masaları falan da yok. Hani yerde uzanarak ya da minder üstünde oturarak dersi yaptıkları için ben de vicdanen altı ders yapma taraftarı olmadım... Harf grupları bitene kadar altı ders yaptım sonra dört derse düşürdüm (Ö.14, 18.05.2021). 
Öğretmenlerin ifadelerinden de anlaşılacağı gibi yetişkinlerin dahi uzun saatler ekran başında kalmakta zorlandığı bu süreçte henüz altı yaşını yeni doldurmuş çocukların ders işlemek için her gün altı ders saati ekran başında kalmaları öğretmenleri zor durumda bırakmış bazı öğretmenler ise bu soruna kendilerince bir çözüm bulmak zorunda kalmışlardır.

\section{Velilerin Uzaktan Eğitim Sürecindeki Bilinçsiz Davranışları}

Veliler uzaktan eğitim sürecinde çocuklarına nasıl yardımcı olabilecekleri konusunda yeterince bilgi sahibi olmadıklarından dolayı da bazı sorunlar yaşanmıştır. Bununla ilgili çalışmaya katılan öğretmenlerden 10 tanesi çeşitli sorunlar sıralamışlardır ancak burada bu sorunlardan birkaç tanesine yer verilecektir.

Illk okumaya başladığım zaman da bunu çok zorlandım. Okuma videosu istiyordum yavaş yavaş okumaya geçtiğimizde çocukları ezberleten velilerim vardı mesela. Yani fark edemeyeceğimi düşünüyorlar ama bunun eğitimini aldım. Çocuk okuyamıyor, ezber yapıyor. Bunun yanlış olduğunu anlatmaya çalıştım (Ö.6, 19.05.2021).

Ailelerin etkisi okumada hissedildi. Bu çok net. Çünkü çocuklarını sürekli düzeltiyorlar, yanındalar. Ama bir süre sonra şunu fark ettim. Derse tek başına giren öğrenciler daha kazançlı çıktılar. Tabir yerindeyse düşe kalka öğrendiler. Kendi başlarına öğrendiler ama okula döndüğüm zaman fark ettim ki kendi başına kalabilen 10 tane öğrencim vardı. Diğerleri duramadılar. Hani her zaman dedim yardım yapalım ama kısıtlı yapalım diye. Normalde biz okuldayken anneler diğer çocukları görmüyorlardı. Herkes kendi çocuğunu biliyordu. Ama burada baktılar kendi çocuğundan daha iyiler var o zaman ekstra yardımlar başladı. Mesela bir tane öğrencimin sınıfın en iyisi olduğunu düşünüyordum okula bir gittim okuma konusunda sınıfın en kötüsüydü (Ö.7, 01.05.2021).

Tam verim alabilmek için ikinci olarak velilerin bilinçlendirilmesi gerekiyor. Örnek vermem gerekirse tam harf yazımını öğretirken arkadan televizyon sesleri geliyor. Ailesinden birisi televizyon izliyor. Çocuğun tüm dikkati bir anda televizyona kayıyor. Bunun dışında okuma yaparken bir anda ben babama bakacağım diyerek kalkıp gidiyor. Bu noktada ailelerin bilinçli bir şekilde dersi takip etmesi için elinden geleni yapması gerekiyor (Ö.12, 24.05.2021).

Öğretmen görüşlerinden de anlaşıldığı üzere bazı aileler uzaktan eğitim sürecinde yeterince bilinçli davranamamıştır. Bazı aileler çeşitli bahaneler üreterek çocuklarını uzaktan eğitim derslerine girdirilmemişler, çocuklara okuma metinlerini ezberleterek sanki çocuk o anda okuyor gibi videolar çekmişler ve öğretmene göndermişler ya da aynı odada uzaktan eğitim dersi sırasında televizyon açarak çocuğun dikkatini dağıtmışlardır. Kendi çocuklarının diğer çocukların gerisinde kaldığını düşünen aileler ise okuma etkinlikleri yapılırken çocuklarına gizli gizli kopya vermişler, yani metni çocuklarının yerine okumuşlar ve aslında fark etmeden çocuklarının okumayı öğrenme sürecini sekteye uğratmışlardır.

\section{Ailelerin Maddi Yetersizliklerine Bağlı Sorunlar}

Bazı ailelerin maddi yetersizlikleri de uzaktan eğitim sürecinde aksamalara sebep olmuştur. Ailelerin maddi yetersizliklerden kaynaklı sorunlara ilişkin öğretmen görüşleri de şu şekildedir:

Ben dedim ki yavrum dedim ya ses geliyor sürekli senden, madem öyle dedim git öteki odada otur. Sonra veli devreye girdi, hocam dedi bir tek soba bizim bu odada yanıyor dedi. Çok mahcup oldum, hiç düşünemedim ben onu. Hani köy evi. Çocuk üşüyor, başka odaya geçme şansı yok (Ö.3, 07.06.2021).

Türkiye şartlarında ... çoğu öğrencinin internet imkânı yok... Hani başta dağıtılmadı sonda dağıııldı. Yani aynı anda bütün öğrenciler aynı şartlarda başlamadığı için verimde düşüklük yaşadık diye düşünüyorum. Ama avantajı yaşayan sınıflar olmuştur. Biraz daha maddi geliri iyi olan sınıfların durumu daha iyidir diye düşünüyorum. Yani imkân azaldıkça sıkıntı artıyor, verim düşüyor (Ö.9, 01.05.2021). 
(Sınıfımda) dört kişinin internet fırsatı olmadığı için giremiyorlardı. Yani kardeş sayısı çok fazla. Evde biraz öncelik diğer kardeşlerde ya da imkân yok. Tablet, telefon gibi. Bunların eksiklerini giderebilseydik onlar da derslere katılım sağlayacağı için verim artırılabilirdi (Ö.11, 26.05.2021).

Özellikle kırsal kesimlerde yaşayan kimi aileler sobalı evlerde oturmakta ve tek odada soba yandığı için uzaktan eğitim dersi sırasında bütün aile fertleri aynı anda ders yapılan odayı kullanmaktadırlar. Doğal olarak ortamda oluşan ses hem öğrencinin dikkatini dağıtmakta hem de dersin akışını olumsuz etkilemektedir. Öğretmenlerin de vurguladığı gibi kimi evlerde internet erişimi sınırlı, kimi evlerde ise kardeş sayısı fazla olduğu için bütün çocukların aynı anda tablet, telefon ya da bilgisayarlara erişimi mümkün olmuyor. Bu durum da öğrencilerin uzaktan eğitim derslerini takip etmelerine büyük bir engel oluşturuyor.

\section{Ilk Okuma Yazma Öğretiminde Seslerin Çıkarılmasına ve Yazım Yönlerine ilişkin Sorunlar}

Uzaktan eğitim aracılığıyla çocuklara ilk okuma yazma öğretimi sürecinde de çeşitli zorluklar yaşanmıştır. Öğretmenlerin ifadeleri şu şekildedir:

Bakan Bey yazılarla ilgili bir şey açıkladı. Yazının uzaktan eğitimde zor öğretildiğini söyledi. Kesinlikle haklı. Yani yazı tamamen birebir olur. Yani çocuk yapacak yapamazsa elinden tutacaksın, beraber yazacaksın. Harflerin nereden döneceğini bilecek vs. Bu birebir temas olmayınca ... olmuyor. O yüzden okumada verim aldım ama yazmada yanında olamadı̆ı̆m için verim alamadım (Ö.1, 14.06.2021).

Öğrencinin yazılarını kameradan görmem gerekti. Hani öğrenci kameradan gösteriyor ama düzeltme şansın çok zor oluyor... Ben harfi yazamıyorum, sadece mesela harfin nasıl olması gerektiğini anlatmak zorunda kalıyorum. Onlar da anlattığıma göre yapmaya çalışıyorlar ama işte hep yönleri ters oldu. Mesela yukarıdan aşağıya değil, aşağıdan yukarıya yazdılar. Hani uzaktan eğitimde okuma öğretme biraz daha kolaydı yazma değil de (Ö.8, 02.06.2021).

Yani yüz yüzeyken bile zor telaffuz edilebilen " $z$ ", "ş" gibi harfleri uzaktan nasıl yapacağız? Arkadaşlar falan da vardı burada, başta bunu düşündük. İşte videolara falan baktım. Çünkü ekrandan öğretmen olarak anlatmak bir yere kadar. Çünkü ses dediğim gibi düzgün gitmiyor. Hani söylüyorum ama çocuk zor anlıyor. Ben "d" diyorum çocuk "b" anlıyor falan (Ö.14, 18.05.2021).

Öğretmenler, okuma sürecinde telaffuzu zor olan "z", "ş" gibi harflerin ve telaffuzu birbirine yakın olan "b", "d" gibi harflerin okunmasında çeşitli sorunlar yaşandığından bahsetmişlerdir. Ancak yazma sürecinin okuma öğretimine göre daha zorlu geçtiğini ifade etmişlerdir. Uzaktan eğitim sürecinde, öğretmenin çocuğun yanında olup bir yanlış yazım gördüğünde anında geri dönüt vererek düzeltme şansı olmadığı için çocuklarda yazım yanlışları oluşmuştur. Öğretmenler özellikle harflerin yazımında kalemin hangi yöne doğru hareket etmesi gerektiği ile ilgili sorunlar yaşandığına vurgu yapmışlardır.

\section{EBA Platformunun Yetersizliği}

Millî Eğitim Bakanlığı'nın hazırladığı Eğitim Bilişim Ağı'nın (EBA) içerik eksikliği de öğretmenlerin uzaktan eğitim sürecinde yaşadıkları zorluklara verdikleri örneklerden birisi olmuştur:

$E B A^{\prime} n ı n$ biraz öğrencilerin ilgisini çekecek şekilde yeniden düzenlenmesi gerekiyor. Örneğin spor yaptırmak istiyorum, sürekli aynı şeyler var. Sürekli aynı videoları gösterdiğiniz için öğrenciler bıkıyor. Dünkü derste sudoku oynattım. Bir tane sudoku vermişler. Hani oyunları çeşitlendirmeleri gerekiyor. Eğlenceli hale getirilmeli. Kitap okuyoruz ama ilgilerini çekecek kitaplar, mesela fazla türde daha çok böyle hayvanlarla ilgili kitaplar, olsa daha iyi olurdu. Ayrıca birinci sınıfın EBA'daki müfredatı yetersiz. 
Gerçekten çok yetersiz. En son anlattığım konu sesli ve sessiz harfler. Bununla ilgili hiçbir etkinlik yok. O konuda bayağı bir zorluk çektik ama okuma yazmaya yönelik videolar, etkileşimli etkinlikler, onlar çok iyiydi. Ama ilk dönem için kullandık. Hani bayağı birinci sınıf için gerçekten yenilemek lazım. Birinci sınıfa yönelik neredeyse hiçbir şey yoktu (Ö.5, 22.05.2021).

EBA üzerindeki oyunlar daha farklı. Uzaktan eğitime uygun materyaller geliştirilip bunlar kullanılsa... Yani biz kendimiz bunları (materyal geliştirme) ne kadar yapabiliriz, yapıyoruz ama kendimize göre yapmış oluyoruz. Yani biz de bu konuda çok iyi değiliz. Ondan dolayı bu tür içerikler sağlanırsa verim artırılabilir (Ö.8, 02.06.2021).

Öğretmen görüşlerine bakıldığında EBA'nın henüz oyun çağında olan birinci sınıf öğrencilerine uygun yeterince etkinlik içermediği görüşü ön plana çıkmaktadır. Öğretmenler sürekli aynı etkinlikleri yaptırmanın ya da aynı oyunları oynatmanın öğrenciye sıkıcı gelebildiğine dikkat çekmekte ve EBA'nın içeriğinin zenginleştirilmesinin verimi artırabileceğini ifade etmektedirler.

\section{Hizmet İ̧̧i Eğitim Eksikliği}

Öğretmenlerin ifade ettiği bir diğer önemli sorun ise uzaktan eğitim sürecinde nasıl ders vermeleri ve uzaktan eğitim platformlarını nasıl kullanabileceklerine ilişkin bir hizmet içi eğitim almamış olmaları olmuştur.

Yani ilk başta ilk başladığımızda tabi ki biz onu (uzaktan eğitim platformlarını) kullanmayı bilmiyorduk. Hani nasıl olacak bilmiyordum. Öğrencilerin sesini nasıl kapatacağız, nasıl açacağız? Öyle bir süreç geçti bir acemilik devresi geçti daha sonra ama öğrendik ve rahat oldu ama birinci sınıf olması işte biraz zorladı (Ö.5, 22.05.2021).

Biz de (öğretmenler) sürece çok yabancıydık. Bence en büyük sıkıntı buydu. Yani bize uzaktan eğitimle ilgili hiçbir eğitim hiçbir bilgi verilmedi. Yani biz süreç içerisinde Zoom (uzaktan eğitim platformu) kullanmaya varana kadar her şeyi kendimiz çözmek zorunda kaldık. Hani öğretmenleri bir önden hazırlama olmadı (Ö.7, 01.05.2021).

Öğretmenlerin ifadelerinden de anlaşılacağı üzere öğretmenler özellikle ilk etapta uzaktan eğitim platformlarının kullanımı konusunda zorlanmışlar daha sonra süreç içerisinde kendi kendileri öğrenmek durumunda kalmışlardır.

\section{Öğrencilerin Uyum Sorunları}

Birinci sınıf öğrencilerinin uzaktan eğitim sebebiyle yaşadıkları uyum sorunları da öğretmenlerin dikkat çektikleri diğer bir önemli konudur.

Öğrenciler okulu çok kötü tanıdılar okul bu şekilde mi diye düşündüler. O biraz zor oldu. Şöyle hocam, şimdi yıllık plan akademik anlamda ilerledi ama oryantasyon diye de bir şey var. Birinci sınıflar için bu çok önemli. Hani okula ilk defa geliyorlar çoğu ya, oryantasyon anlamında bazı etkinlikler yapabiliyorduk. Okuldayken güzel oyunlarla destekliyorduk. Uzaktan eğitimde bu konu (oryantasyon konusu) çok sıkıntı yarattı (Ö.5, 22.05.2021). Illk zamanlarda çocukların okula alışması zor oldu. Uzaktan eğitime de alışması zor oldu. Şimdi biz okullarda maskeliyiz. Maskeli olduğumuz için çocuklar hani bizi direkt göremedi. Böyle o sıcaklığı veremedik (Ö.9, 01.05.2021).

Öğretmenler yüz yüze eğitim sırasında öğrencilerin okula uyumu için çeşitli oyunlar oynatıp etkinlikler yaptırarak okulu çocuğa sevdirebildiklerini ancak uzaktan eğitim sürecinde bu konuda sorun yaşadıklarını ifade etmişlerdir. Okulların uzaktan eğitimden yüz yüze eğitime döndüğü dönemlerde bile yüzlerde maske takılı olduğu için öğrenciyle iletişim kurmakta zorlandıklarını ifade etmişlerdir. 


\section{Öğretmenin Üzerinde Baskı Hissetmesi}

Bunların yanı sıra uzaktan eğitim sürecinde canlı dersler esnasında üzerlerinde baskı hisseden öğretmenler de olmuştur:

Bir de şöyle bir dezavantajı var. Biri bizi gözetliyor evi gibi. O da biraz psikolojik baskı oluşturuyor bizde. İster istemez çocuğa sen şurayı oku bile diyemiyorum (Ö.7, 01.05.2021).

...Çünkü bunu yapmaya başladığımda velilerden internetimiz az şarkı oyun yerine ders yapsanız daha iyi olur gibi tepkiler aldım. Dolaylı olarak öğrencilerin tamamen öğretimine odaklanmak zorunda kaldım (Ö.10, 07.06.2021).

Uzaktan eğitim dersleri özellikle birinci sınıflarda yalnızca öğrencilerin değil çoğu zaman ailenin de katılımıyla gerçekleştiği ve öğretmenin her hareketi, ağzından çıkan her söz de veliler tarafından takip edildiği için bazı öğretmenler ders esnasında üzerlerinde psikolojik bir baskı hissetmişler ve sınıflarındaki kadar rahat ders işleyememişlerdir. Bazı veliler tarafından öğretmenlerin yaptığı etkinlikler ya da oynattığı oyunlar dahi eleştirilmiş, öğretmenlerden bunlarla zaman kaybetmeyip konuyu anlatmaları istenmiştir.

\section{Öğretmenlerin Uzaktan Eğitim Aracılığıyla Illk Okuma Yazma Öğretimleri}

Öğretmenlerin uzaktan eğitim sürecinde yaşadıkları genel sorunlar yukarıda ele alınmıştır. íkinci alt problemde ise "Küresel salgın sürecinde uzaktan eğitim aracılığıyla ilk okuma yazma öğretimi nasıl gerçekleştirilmiştir?" sorusuna cevap aranmıştır. Katılımcılar, 2020-2021 eğitim öğretim yılııın önce yüz yüze başlayıp sonra uzaktan eğitime dönmüş olmasının işlerini çok kolaylaştırdığını ifade etmişlerdir. Dönem başında yüz yüze eğitim süresince çocukların fiziksel yeterlilikleri ve intiyaçları ile ilgili gözlem yapan öğretmenler uzaktan eğitime geçildiğinde de çocukların bireysel ihtiyaçlarına yönelik uygulamalar yapabilmişlerdir. İinci alt probleme ilişkin bulgular altı başlık altında Tablo 3'te sunulmuştur.

Tablo 3.

Öğretmenlerin Uzaktan Eğitim Aracılığıyla Ilk Okuma Yazma Öğretimleri

\begin{tabular}{|c|c|c|c|}
\hline Tema & $f$ & $n$ & Görüş Belirten Katılımcılar \\
\hline Ders Planlarının Uzaktan Eğitime & & & \\
\hline $\begin{array}{l}\text { Göre Güncellenmemesi ve Yüz Yüze } \\
\text { Eğitim Materyallerin Kullanılması }\end{array}$ & 13 & 14 & $\begin{array}{l}\text { O.1, 0.2, } 0.3,0.4,0.5,0.6,0.7,0.8,0.9 \text {, } \\
\text { Ö.10, Ö.11, Ö.12, Ö.13 }\end{array}$ \\
\hline $\begin{array}{l}\text { Web Tabanlı Platformların } \\
\text { Kullanılması }\end{array}$ & 12 & 14 & $\begin{array}{l}\text { Ö.1, Ö.2, Ö.3, Ö.4, Ö.5, Ö.6, Ö.7, Ö.8, Ö.9, } \\
\text { Ö.11, Ö.13, Ö.14 }\end{array}$ \\
\hline Videoların Kullanılması & 11 & 14 & $\begin{array}{l}\text { Ö.1, Ö.2, Ö.4, Ö.5, Ö.6, Ö.9, Ö.10, Ö.11, } \\
\text { Ö.12, Ö.13, Ö.14 }\end{array}$ \\
\hline Veli Desteğinin Sağlanması & 10 & 14 & $\begin{array}{l}\text { Ö,1, Ö.3, Ö.4, Ö.5, Ö.6, Ö.9, Ö.10, Ö.11, } \\
\text { Ö.13, Ö.14 }\end{array}$ \\
\hline Oyun Temelli Öğretim Yapılması & 7 & 14 & Ö.2, Ö.4, Ö.5, Ö.7, Ö.8, Ö.10, Ö.11 \\
\hline $\begin{array}{l}\text { Öğrencilerin Gruplar Halinde Derse } \\
\text { Alınması }\end{array}$ & 2 & 14 & Ö.9, Ö.10 \\
\hline
\end{tabular}

\section{Ders Planlarının Uzaktan Eğitime Göre Güncellenmemesi ve Yüz Yüze Eğitim Materyallerinin KullanıIması}

Öğretmenler, uzaktan eğitim sürecinde de yüz yüze eğitimdeki ders planlarına paralel bir ders planı ile ilk okuma yazma derslerini yürütmeye çalışmışlardır. Yüz yüze eğitim sürecinde derslerde kullandıkları materyalleri de büyük ölçüde uzaktan eğitim sürecinde kullanmaya devam etmişlerdir.

Ö.3: Yüz yüze uyguladığımız (ders) planına göre gitti. Normal planlarımız nasılsa onu hiç bozmadım (07.06.2021). 
Ö.8: Yüz yüze eğitimde kullandığım materyalleri aktarmaya çalıştım. Sadece şu oldu, burada bilgisayardan direk bulmuş oldum. Kırtasiyeden almamıza gerek kalmadı... Son zamanlar işte eee kitapları zaten indirdim... Şimdi çeşitlilik olarak aslında uzaktan eğitimde daha fazla çeşitlilik vardı. Hani elimizde internet bilgisayar hani bir sürü kullanabileceğiniz şey vardı ve hatta oyunlar, ekran üzerinden oyunlar oynadık (02.06.2021).

Ö.9: Planlamada yüz yüze eğitime göre yakın gitti diyebiliriz. Belki normal planlamaya göre daha hızlı oluyor... Yüz yüze eğitimdeki bazı etkinlikleri uzaktan eğitimde de kullanabildik. Mesela oyun hamurları ile aynı şeyi yapabiliyoruz. Fasulyeleri, sayı çubuklarını hala yaptırabiliyoruz çocuklara. İşte bunlardan harfleri oluşturma gibi etkinlikleri kullanabiliyoruz (01.05.2021).

Ö.10: Tabi normal plana sadık kalmaya çalıştık ama kalamıyorsun. Kazanımları falan takvime göre yaptık. Ancak yüz yüze eğitimde olduğu gibi plana uymadık yani onu söyleyeyim açık ve net. E biraz daha şöyle söyleyeyim, şimdi belli başlı kişilerle katılıyoruz canlı derslere. Sürekli bunlarla hızlı gittik. Mesela ben tahmin ettiğimden daha hızlı bitirdim mesela kazanımları (07.06.2021).

Ö.11: Ben çocuklarla birlikte etkinlikler yaptım. Sağ olsun velilerim de yardımcı oldular ders esnasında. Dediğim gibi hani harfle ilk yazdıırken oyun hamuru çok fazla kullandık. Sürekli her hafta sonu bir etkinlik hazırladım. Yazdırmaya yönelik kesme yapıştırma olsun ya da ne bileyim böyle fasulyeler, notlar kullandım. Tıraş köpüğü kullandık. Yani burada o zaman bir nevi yüz yüze eğitimde kullanacağım etkinlikleri kullanmaya gayret ettim (26.05.2021).

Öğretmenlerin görüşlerine bakıldığında, öğretmenlerin ilk okuma yazma derslerini planlarken yüz yüze eğitim sürecindeki gibi planladıkları ancak bazen bu plana sadık kalamadıkları görülmektedir. Uzaktan eğitim derslerine katılan az sayıda öğrenci olduğu için ve bu öğrenciler derse istekli bir şekilde katıldıkları için onlarla öngörülenden daha hızlı yol alınmıştır. Öğretmen görüşlerinden de anlaşılacağı üzere, öğretmenler yüz yüze eğitim sürecinde kullandıkları birçok materyali ve etkinliği (harflerin yazımında oyun hamuru kullanmak, fasulye kullanmak, kesme-yapıştırma etkinlikleri vb.) velilerin de yardımını alarak uzaktan eğitim sürecinde de kullanmışlardır. Kullanılan çevrim içi platformlar bazı öğretmenlerin kullandıkları materyalleri zenginleştirmesine (ders kitabı dışında yardımcı e-kitaplar kullanmak gibi) ve kırtasiyeye gitmeden ders materyali hazırlamasına da olanak sağlamıştır.

\section{Web Tabanlı Platformların Kullanılması}

Gerçekleştirilen görüşmelerde 14 katılımcıdan 12 tanesi derslerini zenginleştirmek amacıyla uzaktan eğitim süresince EBA dışındaki web tabanlı eğitim platformlarını da kullandıklarını ifade etmişlerdir. Öğretmenlerin ifadelerinden bazıları şu şekildedir:

Ö.2: Illk üç ders okuma yazma ile ilgili bir video izle, bir dikte çalışması, sonrasında her gün tabi bir online oyun buluyorum. O iyi oluyordu. Her gün değişik oyunlar oluyor zaten. Ondan sonra kalan derslerde diğer dersleri işliyorum, şeyden, Morpakampüs falan. Sistem tıkır tıkır işliyordu... Morpakampüs bu arada biliyorsunuzdur, belki şeyi biliyor musun Okulistik? ikisini de kullanıyorum. Allah razı olsun onları yapanlardan. Yani mükemmel bir site ikisi de. Bizim işimizi de kolaylaştırıyorlar, çocukların algısını da yükseltiyor. Çizgi filmde olunca ilgilerini de çekiyor (15.06.2021).

Ö.6: EBA'yı kullandım ama etkinlik olarak Okulistik kullandım. Ben o sitenin etkinliklerini beğendiğim için orayı kullandım ve düzeylerine uygun olduğunu düşünüyorum (19.05.2021).

Ö.8: Yani bu süreçte tabi (EBA) yeterli olmadığı için mesela diğer hocalarımızdan Okulistik, Morpakampüs gibi birçok site öğrendik. Bir de Wordwall diye bir site kullandım. Çünkü orada kelime oyunları var, işte bulmaca şeklinde, çarkıfelek şeklinde, işte bulutlar var (02.06.2021). 
Ö.9: Materyal ve etkinlik olarak çeşitli şeyler var, siteler. İşte Morpakampüs gibi, Okulistik gibi. Bunların imkanlarından faydalanıyoruz. Onun dışında bu şeyler var. Yardımcı animasyonlar falan oluyor ya onlardan faydalanıyoruz. Bunlarla çok rahat bir şekilde harfleri falan öğrenebiliyorlar (01.05.2021).

Ö.11: ... Okulistik programını çok fazla kullandım. Harf tanıtımında orayı çok kullandım. Bi de Ders Ekranda diye bir uygulama vardı. Orada oyunlar vardı. Hece okutma, işte hızlı okuma yaptırma gibi. Çocuklar hem böyle oyun oynuyorlar hem böyle birbirleriyle yarışıyorlardı. Onu da seviyorlardı, onu kullandım (26.05.2021).

Öğretmenler, çocukların web tabanlı eğitim platformlarını kullanmaya istekli olduklarını ve bu platformlarda bulunan etkinliklerden keyif aldıklarını ifade etmişlerdir. Bu platformlarda her gün farklı bir oyun, etkinlik ya da konuyla ilgili bir çizgi film bulabildiklerini ve sistemin güzel çalıştığını belirtmişlerdir.

\section{Videoların Kullanılması}

Katılımcılar ile gerçekleştirilen görüşmeler, öğretmenlerin gerek hazır videoları gerekse kendi hazırladıkları videoları uzaktan eğitim aracılı̆ııla ilk okuma yazma öğretimi sürecinde aktif olarak kullandıklarını göstermektedir.

Ö.1: Benim yaklaşık okul açıkken zaten 12-13 harf bitti. Uzaktan eğitime geçince de çoğunu videodan hallettik, sonra da çocuk mantığı kavrayınca anne babaya atış serbest (istediğinizi okutabilirsiniz) dedim (14.06.2021).

Ö.2: Şimdi biz... okuma yazma sürecinde sistem belli. Her gün ne yaptığımız belli. îlk üç ders okuma yazma ile ilgili bir video izle, bir dikte çalışması, sonrasında her gün tabi bir online oyun buluyorum. O iyi oluyordu (15.06.2021).

Ö.11: Dört tane öğrenci hiç derse girmiyordu. Bunlar için video çekiyordum ben. Whatsapp'tan yolluyordum. Videoda kendim anlatıyordum. Yazımını gösterip video atıyordum. Bu şekilde başlangıç yapmıştık (26.05.2021).

Ö.13: ... Ama harf öğretme sürecinde hiçbir sıkıntımız olmadı. Ağırlığı harfleri vererek... benim yüz yüze eğitimde uygulayacağım teknikleri, işte gerek videolardan gerek farklı uygulamalardan destek alarak, o şekilde ilerledik. Yani çok sıkıntımız olmadı (14.05.2021).

Uzaktan eğitim aracılığıyla ilk okuma yazma öğretirken öğretmenlerin videoları aktif olarak kullandıkları görülmektedir. Bu çalışmaya katılan 14 katılımcıdan 11 tanesi derslerinde video kullandıklarını ifade etmişlerdir. Hazır videoların yanı sıra hem sesi tanıtmak hem de harfin nasıl yazılması gerektiğini göstermek amacıyla öğretmenlerin de videolar hazırlayıp derse katılamayan öğrencilerle paylaştıkları katııımıların ifadelerinde dikkat çekmektedir.

\section{Veli Desteğinin Sağlanması}

Uzaktan eğitim aracılı̆̆ıla ilk okuma yazma öğretimi sürecinde öğrencilerle fiziksel temas kuramayan öğretmenlerin en büyük yardımcıları veliler olmuştur. Katılımcılar, gerçekleştirdiğimiz görüşmelerde şu ifadelere yer vermişlerdir:

Ö.4: Okul ortamında olsaydık bir materyal geliştirmek için orada kılavuz olarak rehber olarak ben olacaktım ama bu noktada veliler yardımcı oldular. O esnada birazcık onların üstüne yük bindi. Bu sefer planlayıcı biz olduk, yönlendirici onlar oldular. Birazcık uygulama aşamasında çocuğun eli kolu ayağı oldular (27.05.2021).

Ö.6: Ayrıca öğrenci özelliklerini devreden çıkarırsak verim için bir değerlendirme yaptığımızda 10 üzerinden altı öğretmense dört de ailedir derim ben. Ailenin verim için yani oldukça yüksek olduğunu düşünüyorum. Çünkü ödev takibini onlar yapıyor. Ders başında yine onlar duruyor, takip edip etmediğini, bilgisayarın başında ne yaptıklarını onlar takip ediyor (19.05.2021). 
Ö.9: Mesela veliler bire bir ilgileniyorlar. Yani yardımcı olabiliyor, biz de ekrandan hani şöyle yap böyle yap diye onları yönlendiriyoruz. Bu bir avantaja dönüşebilir... Anne baba ilgili oldu mu daha hızlı ilerleyebiliyorum. Aileler ilgili oldu mu çocuğu strese sokmayacak şekilde ilerleyebiliyoruz (01.05.2021).

Ö.10: Şu şekilde inanıyorum verim aldığıma. Mesela derste çocuk velisi yok, kontrol edemiyoruz bazen çocuğu... Uzaktan eğitimde bizim için aslında her çocuğun yanında derse girerken velisi olması iyi oldu. Abisi-ablası, annesi-babası yanında olduğu için hem onlar sayesinde takibini yapabildim hem biraz daha çocuklar baskı demiyim de dikkatleri dağılmadan diyeyim dersi dinlediler. Velilerin desteğiyle güzel bir süreç geçirdik (07.06.2021).

Katılımcıların ifadelerinden velilerin öğretmenlerin rehberliğinde çocuklarının okuma yazma öğrenme sürecine katkı sağladıkları anlaşılmaktadır. Her gün uzun bir zaman bilgisayar başında kalan birinci sınıf çocuklarının derse ilgisi azalabilmekte ve dersi takip etmekte zorlanabilmektedirler. Katılımcıların ifadelerinden de anlaşılacağı üzere bu noktada velilerin desteği son derece önemlidir. Gerek çocukların düzeni bozmandan dersi takibi noktasında, gerek öğretmenin verdiği direktiflerin çocuğa açıklanması noktasında, gerekse etkinliklerin yaptırılması ya da kontrolü noktasında velilerin verdiği destek okuma yazma öğretimi sürecine olumlu yansımıştır.

\section{Oyun Temelli Öğretim Yapılması}

Çalışmaya katılan öğretmenlerden bazıları ise uzaktan eğitim süresince oyunlar oynatarak ilk okuma yazma eğitimi vermeye çalıştıklarını ifade etmişlerdir.

Ö.2: Illk okuma yazma ile ilgili mesela isim-eşya oyunu var, onu oynadık birkaç kere. İsim bulmaca oynadık mesela. F harfi ile ilgili bildiğiniz isimleri herkes yazsın falan. Tabi ailelerden destek alıyorlar ama yazma konusunda değil. Kendileri yazıyorlar (15.06.2021). Ö.7: Çocukların daha çok ilgisini çekecek şeylerle hani daha çok dikkatini çekecek şeylerle programı yapmaya çalışım. Vermemiz gereken süreç uzundu. Birinci sınıflar çok küçük, onların bu sürece adapte olması da biraz sıkıntılıydı. O yüzden bol bol oyunlar yani ne kadar oyun varsa hepsini oynayarak ilerledik aslında... İnanın yüz yüzeye göre bu süreçte materyal daha fazlaydı. Dediğim gibi dramalarımız vardı. Oyunlar ve PC (bilgisayar) oyunlarına çok yöneldik. Mesela her harf için en az iki oyun hazırladık. Çünkü buna mecburdum onlara öğretmek için (01.05.2021).

Ö.10: ...Okuma yazma ile ilgili çeşitli birkaç kaynaktan aldım. CD’den yükledim ve görüntü olarak yansıttım. Oradan ilerledik. Oyun vesaire de vardı. Bunların içerisinde çeşitli oyunlar var. Hani artık onlara göre, çocuklar da dokunup yapamıyorlar (sınıftaki gibi akıllı ekrana dokunarak etkinlik yapamıorlar). Ancak ben orada mesela duruyorum. Soruyorum mesela, o şekilde yaptık... (07.06.2021).

Katılımcıların da ifade ettiği gibi birinci sınıf öğrencilerinin uzaktan eğitim sürecine adapte olabilmesi için oyunlar oynatmak etkili bir yol olmuştur. Öğretmenler, çocukların yazma becerisine de katkı sunacak şekilde oyunlar seçmişlerdir. Çeşitli bilgisayar oyunları da ilk okuma yazma öğretiminde öğretmenler tarafından kullanılmıştır.

\section{Öğrencilerin Gruplar Halinde Derse Alınması}

Küresel salgın başladıktan sonra salgının seyrine göre Türkiye'de kimi zaman yüz yüze eğitim kimi zaman da uzaktan eğitim verilmiştir. Yüz yüze eğitim verildiği dönemlerde, Millî Eğitim Bakanlı̆̆ı tarafından sınıfların iki gruba ayrılarak bir grubun Pazartesi, Salı diğer grubun da Perşembe, Cuma günleri yüz yüze eğitim alması, Çarşamba günleri ise tüm sınıfın uzaktan eğitim derslerini takip etmesi şeklinde bir planlama yapılmıştır. Ancak uzaktan eğitim verildiği dönemlerde böyle bir düzenlemeye ihtiyaç duyulmamış tüm öğrencilerin hafta içi her gün uzaktan eğitim derslerine devam edecek şekilde 

Öğretimi

bir planlama yapılmıştır. Durum böyleyken uzaktan eğitim sürecinde de bazı sınıflarını gruplara bölerek ilk okuma yazma öğretimi yapmayı tercih etmişlerdir.

Ö.9: Bir de ben şöyle bir şey yaptım. Normalde altı saat ders vermem gerekiyor ama ben dört saat yaptım. Çocukları böldüm. Normalde Pazartesi-Salı, Perşembe-Cuma grubu olarak biliniyor. Ben hayat bilgisi ve matematik derslerini bütün sınıfla birlikte yaptım. Ama ilk okuma yazma öğretimini bölüp iki saat sınıfın bir bölümüne iki saat de sınıfın diğer bölümüne şeklinde yaptım (01.05.2021).

Ö.10: Sınıfı dediğim gibi birleştirilmiş sınıf mantığı aldım. Canlı derse katılanlar, ödev yapanlar, hiçbir şey yapmayanlar diye üç gruba böldüm (07.06.2021).

Katılımcıların büyük bir kısmı bazı öğrencilerin dersleri güzel takip ettiklerini, bazılarının sadece ödevleri yapıp Whatsapp gibi uygulamalar aracılı̆̆ı ile öğretmenlere ilettiklerini ve bazılarının da dersleri düzenli takip etmediklerini/edemediklerini ifade etmişlerdir. Bu durumda öğrencilerin okuma yazma düzeyleri de birbirinden farklılık gösterdiği için bazı öğretmenler çareyi öğrencileri gruplara bölüp düzeylerine göre eğitim vermekte bulmuşlardır.

\section{Tartışma ve Sonuç}

Çalışmanın bulgularından da anlaşılacağı üzere her ne kadar uzaktan eğitim süreci yüz yüze eğitime ara verildiği dönemlerde eğitimin aksamaması için bir çözüm olarak yürürlüğe girmiş olsa da henüz ne sistemin ne de sistemi kullanan öğretmen ve öğrencilerin buna hazır olmamasından kaynaklı olarak birçok sorunu da beraberinde getirmiştir. Uzaktan eğitim sürecinin başladığı dönemlerde öğretmenlerle yapılan çalışmalara bakıldığında öğretmenlerin kendilerini uzaktan eğitim konusunda yetersiz gördükleri bulgusuyla karşılaşılmaktadır (Bakioğlu ve Çevik, 2020). Bu çalışmada da buna paralel olarak öğretmenlerin özellikle uzaktan eğitime geçildiği dönemlerde hizmet içi eğitim alamadıklarından şikayetçi oldukları, hem nasıl bir eğitim vermeleri gerektiğini hem de uzaktan eğitim platformlarını nasıl kullanacaklarını bilmemelerinden kaynaklı olarak kaygılı oldukları görülmüştür.

Bunun yanı sıra çeşitli çalışmalarda öğrencilerin derse ilgisiz oldukları, derslere katılımın düşük olduğu ve fırsat eşitsizliklerinden kaynaklı sorunlar yaşandığı belirtilmektedir (Bayburtlu, 2020). Bu çalışmada da öğrencilerin uzaktan eğitim sürecine uyum sorunu yaşadıkları, kimi zaman ailelerin bilinçsiz davranışları sebebiyle kimi zaman da maddi yetersizlikler sebebiyle öğrencilerin uzaktan eğitim derslerine girmedikleri / giremedikleri bulgusuna ulaşılmıştır. Yine daha önceki çalışmalara paralel olarak bu çalışmada internet ve elektrik altyapısındaki yetersizliklere bağlı olarak öğrencilerin dersleri düzenli takip edememeleri ve velilerin bilinçsiz davranışları (çocuklarına kopya vermek vb.) olmaları öğretmenler tarafından ifade edilen sorunlar olmuştur (Kavuk ve Demirtaş, 2021).

Bu çalışmada öğretmenlerin en çok üzerinde durduğu sorunlardan bir tanesi de uzaktan eğitim sürecinde ilkokul birinci sınıf öğrencilerinin her gün altı ders saati ekran başında tutulması olmuştur. Öğretmenlerin bir kısmı bu soruna karşı kendilerince önlem alarak ders saatini dört saate düşürmüşlerdir. Yetişkinlerin dahi o kadar uzun süre dikkati dağılmadan ekran başında kalması mümkün değil iken özellikle ilkokul düzeyindeki öğrencilerin bu kadar ekran başında kalmaları doğru değildir. Uzaktan eğitimin devam etmesi ya da ileriki yıllarda yüz yüze eğitimin desteklenmesi amacıyla kullanılması durumunda mutlaka günlük ders saatinin sınıf düzeylerine uygun olarak ayarlanması ile ilgili bir düzenleme yapılması gerekmektedir.

Illk okuma yazma öğretimi sürecinde seslerin çıkarılması ve seslerin yazım yönlerine ilişkin çocukların yaptığı hatalar da öğretmenlerin belirttiği bir diğer önemli sorundur. Bazen internet kalitesine bazen de uzaktan eğitim sırasında kullanılan cihazın kalitesine bağlı olarak uzaktan eğitim platformunda sesler her zaman çok net olarak iletilememektedir. Bu durum da çocuğun sesi yanlış duymasına ve sesi yanlış çıkarmasına sebep olabilmektedir. Yine sesin şeklini ekrandan gören çocuk öğretmenin sesi yazarken elini hangi sırayla hangi yönlere doğru hareket ettirdiğini takip edemeyebilmekte ve sesin yazımını yanlış öğrenebilmektedir. Bu soruna yönelik bazı öğretmenler videolar çekerek öğrencilerin aileleriyle paylaştıklarını ya da çeşitli web platformlarında bulunan ses öğretimine ilişkin hazır videoları kullandıklarını ifade etmişlerdir. Videoların ve web platformlarındaki 
içeriklerin kullanımı çocuğun uzaktan eğitim sürecinde sesi doğru çıkarmayı ve sesi doğru yazmayı öğrenmesinde tercih edilebilecek etkili yöntemlerden birisi olarak karşımıza çıkmaktadır.

Öğretmenlerin bir kısmı da EBA içeriklerinin özellikle birinci sınıf düzeyi için çok yetersiz olduğunu ve bu sebeple EBA'nın yanı sıra çeşitli web platformlarını kullandıklarını ifade etmişlerdir. Millî Eğitim Bakanlığı halen EBA platformunun içeriğini genişletmek için çeşitli çalışmalar yürütmektedir ancak diğer web platformlarıyla karşılaştıııldığında halen içeriğin yeterli düzeyde olmadığı görülmektedir. Bu çalışmalara hız verilerek EBA içeriğinin her sınıf düzeyinde zenginleştirilmesi, özellikle ilkokul düzeyi için çeşitli oyun ve eğlenceli etkinliklerle içeriğin çocuklar için dikkat çekici hale getirilmesi gerekmektedir.

Bazı öğretmenler uzaktan eğitim sürecinde karşılarında sadece öğrencilerin değil ailelerin de olduğunu, bu sebeple kimi zaman doğrudan ailelerin sürece müdahil olmasıyla kimi zaman da sadece ailelerin de o anda ders dinlediğini düşünerek kendilerini rahat hissedememişler, üzerlerinden psikolojik bir baskı hissetmişlerdir. Öğretmenlerden bazıları kendilerini izleniyor hissettiklerini ve çocuklara hitap ederken bile zorlandıklarını ifade etmişlerdir. Hem ailelerin derse müdahil olmama konusunda bilinçlendirilmeleri hem de öğretmenlerin sınıf yönetiminin kendilerinde olduğu ve kendilerine güvenip doğru bildikleri eğitimi çocuğa vermeleri gerektiği konusunda cesaretlendirilmeleri gerekmektedir.

Uzaktan eğitim sürecinde bu sorunlar yaşanırken öğretmenlerin okuma yazma öğretimini nasıl gerçekleştirdiklerine baktığımızda yüz yüze eğitim ile dönem başladığı için derslerini eskisi gibi planladıkları ve uzaktan eğitime geçildiğinde de ders planlarında herhangi bir değişiklik yapmadıkları görülmektedir. Uzaktan eğitim aracılığıyla nasıl ders anlatılacağına ve uzaktan eğitim platformunun nasıl kullanılacağına ilişkin bir deneyimi olmayan, durum böyle olduğu halde bu konuda bir hizmet içi eğitim de alamamış olan öğretmenlerin yüz yüze eğitim için yaptıkları ders planlarını uygulamaya devam etmekten başka bir seçenekleri de görünmemektedir. Küresel salgının ilerleyen dönemlerinde hizmet içi eğitim sayfaları hazırlanarak öğretmenlerin kullanımına açılmıştır. Şu anda eğitim modülleri üzerinden hizmet içi eğitim almak mümkündür ancak bu eğitimlerin ne ölçüde yeterli olduğu, öğretmenlerin ihtiyaçlarına ya da uzaktan eğitim sırasında karşılaştıkları sorunlara ne ölçüde ışık tutabildiği akademik olarak çalışıımalıdır.

Öğretmenlerin yüz yüze eğitim sırasında kullandıkları materyallerin büyük bir kısmını uzaktan eğitim sürecinde de kullandıkları, bunlara ek olarak ders planlarında olmasa da çeşitli web platformlarındaki eğitici videoları, oyunları ve etkinlikleri de yoğun olarak kullandıkları görülmektedir. Bu bulgu, alan yazındaki güncel çalışmalarda ifade edilen öğretmenlerin artık uzaktan eğitime ayak uydurarak dersleri yeni teknolojileri kullanarak gerçekleştirdiği (Canpolat ve Yıldırım, 2021) bulgusuyla da paralellik göstermektedir.

Öğretmenlerin yüz yüze eğitimde sınıfta oynattıkları oyunların yanı sıra çeşitli çevrim içi oyunları da yoğun olarak kullandıkları dikkat çekmektedir. Alan yazın tarandığında ilkokul düzeyinde öğrenim gören öğrencilerin de uzaktan eğitim ile birlikte sorumluluk alabildikleri ancak öğrencilerin derslere iyi motive edilmesi gerektiği ifade edilmektedir (Bozkurt, 2020b). Özellikle birinci sınıfta henüz oyun yaşında olan çocukların motivasyonunu arttırmak ve öğrendiklerini pekiştirmek adına oyun temelli bir öğretim modeli kullanmanın doğru olduğu düşünülmektedir.

Velilerin uzaktan eğitim sürecinde aktif olarak rol oynaması ilkokul öğrencilerinin de uzaktan eğitim aracılığı ile aldıkları eğitimin verimini arttırmaktadır (Bozkurt, 2020b). Çalışmaya katılan öğretmenlerin büyük bir kısmı velilerin bilinçli olanlarının sürece büyük katkı sağladıklarını ifade etmişlerdir. Özellikle öğretmenlerin fiziksel olarak çocukların yanında bulunup okurken ya da yazarken yaptığı yanlışlara anında dönüt verememesinin eksikliğini öğretmenlerin yönlendirmesiyle çocuklarını takip eden veliler kapatmıştır. Çocukların derse düzenli katılımının takibi, öğretmenlerin direktiflerinin çocuklara açıklanması, etkinlilerinin yaptııılıp takip edilmesi noktasında velilerin verdiği destek okuma yazma öğretimi sürecine olumlu yansımıştır.

Bu çalışmada öğretmenlerin görüşleri çerçevesinde uzaktan eğitim sürecinde yaşanan sorunların ve uzaktan eğitim aracılığıyla okuma yazma öğretiminin nasıl gerçekleştirildiğinin ortaya konması amaçlanmıştır. Çalışmanın bulguları yalnızca öğretmen görüşleriyle sınırlıdır. Veliler ve öğrenciler gibi konunun diğer paydaşlarıyla yapılacak çalışmalar resmin bütününün görülmesine 
yardımcı olacaktır. Uzaktan eğitim aracılığıyla verilen okuma yazma eğitimine ilişkin velilerin görüşlerinin tespit edilmesi, onların uzaktan eğitim sistemi, öğretmenlerin kullandığı öğretim yöntemleri ve çocukların süreci takip ederken yaşadığı sorunlar üzerine verecekleri bilgiler mevcut durumun daha iyi anlaşılmasına yardımcı olacak ve karar alıı mercilere ışık tutacaktır. Yine çocukların uzaktan eğitim aracılığıyla aldıkları ilk okuma yazma eğitiminin ne kadar etkili olduğuna yönelik çocuklarla yapılacak uzun soluklu nitel çalışmalar da uygulamaların ne kadar başarıya ulaştığı, hangi alanlarda ne tür eksikliklerin oluştuğuna dair yol gösterici nitelikte olacak ve alan yazına katkı sağlayacaktır.

\section{Araştırma ve Yayın Etiği}

Bu çalışmada "Yükseköğretim Kurumları Bilimsel Araştırma ve Yayın Etiği Yönergesi" kapsamında uyulması belirtilen tüm kurallara uyulmuştur. Yönergenin ikinci bölümü olan "Bilimsel Araştırma ve Yayın Etiğine Aykırı Eylemler" başlığı altında belirtilen eylemlerden hiçbiri gerçekleştirilmemiştir.

\section{Etik Kurul İni}

Kurul adı= Uşak Üniversitesi Rektörlüğü Sosyal ve Beşerî Bilimler Bilimsel Araştırma ve Yayın Etiği Kurulu

Karar tarihi $=10.06 .2021$

Belge sayı numarası $2021-129$ sayılı karar

\section{Yazarların Katkı Oranı}

Bu makalede yazarların katkı oranı 1. yazar \%50, 2. yazar $\% 50$ şeklindedir.

\section{Çıkar Çatışması}

Bu çalışmada çıkar çatışması oluşturabilecek herhangi bir durum ya da ilişki bulunmamaktadır.

\section{Kaynaklar}

Adıyaman, Z. (2002). Uzaktan eğitim yoluyla yabancı dil öğretimi. The Turkish Online Journal of Educational Technology, 1(1), 92-97.

Akdemir, Ö. (2011). Yükseköğretimimizde uzaktan eğitim. Yükseköğretim ve Bilim Dergisi, 1(2), 69-71. Akyüz, Y. (1982). Türk eğitim tarihi. Ankara: Pegem Akademi Yayınları.

Alkan, C. (1987). Açıköğretim: Uzaktan eğitim sistemlerinin karşılaştırılmalı olarak incelenmesi. Ankara: Ankara Üniversitesi Eğitim Bilimleri Fakültesi Yayınları.

Altınpulluk, H. (2021). Türkiye'deki öğretim üyelerinin Covid-19 küresel salgın sürecindeki uzaktan eğitim uygulamalarına ilişkin görüşlerinin incelenmesi. Gazi Üniversitesi Gazi Eğitim Fakültesi Dergisi, 41(1), 53-89.

Altıparmak, M. (2011). E-öğrenme ve uzaktan eğitimde açık kaynak kodlu öğrenme yönetim sistemleri. XIII. Akademik Bilişim Konferansı Bildirileri Kitabı içinde (ss. 319-327). Malatya.

Arat, T ve Bakan, Ö. (2014). Uzaktan eğitim ve uygulamaları. Selçuk Üniversitesi Sosyal Bilimler Meslek Yüksekokulu Dergisi, 14(12), 363-374.

Bakioğlu, B. ve Çevik, M. (2020). COVID-19 pandemisi sürecinde fen bilimleri öğretmenlerinin uzaktan eğitime ilişkin görüşleri. Turkish Studies, 15(4), 109-129.

Balaman, F. ve Hanbay Tiryaki, S. (2021). Corona virüs (Covid-19) nedeniyle mecburi yürütülen uzaktan eğitim hakkında öğretmen görüşleri. Itobiad: Journal of the Human \& Social Science Researches, 10(1), 52-84.

Baran, A., \& Sadık, O. (2021). Covid-19 sürecinde sınıf öğretmenlerinin acil uzaktan öğretim tecrübelerinin ve görüşlerinin incelenmesi. Uludağ Üniversitesi Eğitim Fakültesi Dergisi, 34(2), 813-854. https://doi.org/10.19171/uefad.882291

Bayburtlu, Y.S. (2020). Covid-19 pandemi dönemi uzaktan eğitim sürecinde öğretmen görüşlerine göre Türkçe eğitimi. Turkish Studies, 15(4), 131-151.

Bilhan, S. (1991). Eğitim felsefesi. Ankara: Ankara Üniversitesi Eğitim Bilimleri Yayınları. 
Bozkurt, A. (2020a). Koronavirüs (Covid-19) pandemi süreci ve pandemi sonrası dünyada eğitime yönelik değerlendirmeler: Yeni normal ve yeni eğitim paradigması. Açıköğretim Uygulamaları ve Araştırmaları Dergisi, 6(3), 112-142.

Bozkurt, A. (2020b). Koronavirüs (Covid-19) pandemisi sırasında ilköğretim öğrencilerinin uzaktan eğitime yönelik imge ve algıları: Bir metafor analizi. Uşak Üniversitesi Eğitim Araştırmaları Dergisi, 6(2), 1-23.

Bozkurt, A. ve Sharma, R. C. (2020). Emergency remote teaching in a time of global crisis due to coronavirus pandemic. Asian Journal of Distance Education, 15(1), i-vi.

Bozkurt, A., Jung, I., Xiao, J., Vladimirschi, V., Schuwer, R., Egorov, G. ve ark. (2020). A global outlook to the interruption of education due to COVID-19 pandemic: Navigating in a time of uncertainty and crisis. Asian Journal of Distance Education, 15(1), 1-126.

Canpolat, U. ve Yıldırım, Y. (2021). Ortaokul öğretmenlerinin COVID-19 salgın sürecinde uzaktan eğitim deneyimlerinin incelenmesi. Açıköğretim Uygulamaları ve Araştırmaları Dergisi, 7(1), 74-109.

Chmiliar, I. (2010). Multiple-case designs. J. Mills, G. Eurepas \& E. Wiebe (Eds.), Encyclopedia of case study research içinde (pp. 582-584). SAGE Publications.

Clark, J. T. (2020). Distance education. Ernesto ladanza (Ed.), Clinical Engineering Handbook içinde (ss. 410-415). Italy: Academic Press.

Demir, E. (2014). Uzaktan eğitime genel bir bakış. Dumlupınar Üniversitesi Sosyal Bilimler Dergisi, 39, 203-212.

Düzakın, E. ve Yalçınkaya, S. (2008). Web tabanlı uzaktan eğitim sistemi ve Çukurova Üniversitesi öğretim elemanlarının yatkınlıkları. Çukurova Üniversitesi Sosyal Bilimler Enstitüsü Dergisi, $17(1), 225-244$.

Eken, Ö., Tosun, N. ve Tuzcu-Eken, D. (2020). Covid-19 salgını ile acil ve zorunlu uzaktan eğitime geçiş: Genel bir değerlendirme. Milli Eğitim Dergisi, 49(1), 113-128.

Ekici, G. (2003). Uzaktan eğitim ortamlarının seçiminde öğrencilerin öğrenme stillerinin önemi. Hacettepe Üniversitesi Eğitim Fakültesi Dergisi, 24, 48-55.

Erbaş, Y. H. (2021). Covid-19 salgını döneminde eğitim: İlkokuma yazma öğretiminde karşılaşılan sorunlar ve çözüm önerileri. Ana Dili Eğitimi Dergisi, 9(2), 360-380.

Ergün, M. (2009). Eğitim felsefesi. Ankara: Pegem Akademi Yayınları.

Ertürk, S. (1984). Eğitimde program geliştirme. Ankara: Yelkentepe Yayınları.

Gebhardt E., Thomson S., Ainley J., \& Hillman K. (2019). Gender differences in computer and information literacy. New York, NY: Springer Nature.

Gökbulut, B. (2021). Uzaktan eğitim öğrencilerinin bakış açısıyla uzaktan eğitim ve mobil öğrenme. Eğitim Teknolojisi Kuram ve Uygulama, 11(1), 160-177.

Göktaş, Y., Yıldıım, Z., ve Yıldıım, S. (2008). Bilgi ve iletişim teknolojilerinin eğitim fakültelerindeki durumu: Dekanların görüşleri. Eğitim ve Bilim, 33(149), 30-50.

Güneş, F. (2000). Okuma-yazma öğretimi ve beyin teknolojisi. Ankara: Ocak Yayınları.

Hodges, C., Moore, S., Lockee, B., Trust, T. \& Bond, A. (2020). The difference between emergency remote teaching and online learning. 30 Nisan 2021 tarihinde https://er.educause.edu/articles/2020/3/the-difference-between-emergency-remote teaching-and-online-learning adresinden erişilmiştir.

Holmberg, B. (1989). Theory and practice of distance education. New York, NY: Routledge.

Işman, A. (2011). Uzaktan eğitim. Ankara: Pegem A Yayıncılık.

Kaçan, A ve Gelen, ì. (2020). Türkiye'deki uzaktan eğitim programlarına bir bakış. Uluslararası Eğitim Bilim ve Teknoloji Dergisi, 6(1), 1-21.

Karaca, i., Karaca, N., Karamustafaoğlu, N., \& Özcan, M. (2021). Öğretmenlerin uzaktan eğitimin yararına ilişkin algılarının incelenmesi. Humanistic Perspective, 3(1), 209-224.

Karakuş, N., Ucuzsatar, N., Karacaoğlu, M. Ö., Esendemir, N. ve Bayraktar, D. (2020). Türkçe öğretmeni adaylarının uzaktan eğitime yönelik görüşleri. Rumelide Dil ve Edebiyat Araştırmaları Dergisi, $19,220-241$.

Karaman, M. ve Yurduseven, S. (2008). Illk okuma yazma programına ilişkin öğretmen görüşleri. Uşak Üniversitesi Sosyal Bilimler Dergisi, 1(1), 115-129. 
Karatepe, F., Küçükgençay, N. ve Peker, B. (2020). Öğretmen adayları senkron uzaktan eğitime nasıl bakıyor? Bir anket çalışması. Journal of Social and Humanities Sciences Research, 7(53), 1262 1274.

Kavuk, E. ve Demirtaş, H. (2021). COVID-19 pandemisi sürecinde öğretmenlerin uzaktan eğitimde yaşadığı zorluklar. E-Uluslararası Pedandragoji Dergisi, 1(1), 55-73.

Kaya, Z. (1996). Uzaktan eğitimde ders kitapları. Ankara: Gazi Üniversitesi Endüstriyel Sanatlar Eğitim Fakültesi Matbaası.

Kırık, A. (2014). Uzaktan eğitimin tarihsel gelişimi ve Türkiye'deki durumu. Marmara Iletişim Dergisi, $21,73-94$.

Merriam, S. B. (2009). Qualitative research: A guide to design and implementation. San Francisco, CA: Jossey-Bass.

Moore, M. \& Kearsley, G. (2005). Distance education: A system view. Belmont: Wadsworth.

Murphy, C. \& Beggs, J. (2003). Primary pupils' and teachers' use of computers at home and school. British Journal of Educational Technology, 34(1), 79-83.

Newby, T.J., Stepich, D.A., Lehman, J.D. \& Russell, J.D. (2006). Educational technology for teaching and learning. Pearson Merrill Prentice Hall.

Odabaş. H. (2003). Internet tabanlı uzaktan eğitim ve bilgi ve belge yönetimi bölümleri. Türk Kütüphaneciliği, 17(1), 22-36.

Özbay, Ö. (2015) Dünyada ve Türkiye'de uzaktan eğitimin güncel durumu. Uluslararası Eğitim Bilimleri Dergisi, 2(5), 376-394.

Özer, S. ve Turan, E. Z. (2021). Öğretmen adaylarının Covid-19 nedeniyle sunulan uzaktan eğitime ilişkin görüşleri. Turkish Studies - Education, 16(2), 1049-1068.

Punch, K.F. (2014). Introduction to research methods in education. Los Angeles: Sage Publications.

Ruksasuk, N. (1999). Library and information science distance education in Thailand in the next decade. 6551 IFLA Counctt and General Conference içinde (p. 11). Scotland.

Simonso, M., Smaldino, S., Albright, M. \& Zvacek, S. (2003). Teaching and learning at a distance: Foundations of distance education. Charlotte, NC: Information Age Publishing.

Sirem, Ö. ve Baş, Ö. (2020). Okuma güçlüğü olan ilkokul öğrencilerinin Covid-19 sürecinde uzaktan eğitim deneyimleri. Turkish Studies, 15(4), 993-1009.

Sönmez, V. (2017). Öğretim ilke ve yöntemleri. Ankara: Anı Yayınları.

TDK. (2021). Türkçe sözlük. 6 Mayıs 2021 tarihinde https://sozluk.gov.tr/ adresinden edinilmiştir.

Thompson, A. D., Simonson, M. R. \& Hargrave, C. P. (1996). Educational technology: A review of research. Washington, DC: Association for Educational Communications and Technology.

Traxler, J. (2018). Distance learning-predictions and possibilities. Education Sciences, 8(35), 1-13.

Uluğ, F. (1994). Uzaktan eğitim ortamları "Açıköğretim lisesi örneği". Ankara: M.E.B. Film Radyo Televizyonla Eğitim Başkanlığı.

UNESCO, (2020). Startling digital divides in distance learning emerge, 5 Mayıs 2021 tarihinde https://en.unesco.org/news/startling-digital-divides-distance-learning-emerge adresinden erişilmiştir.

Uşun, S. (2006). Uzaktan eğitim. Ankara: Nobel Yayıncılık.

Ünüvar, P. ve Çelik, K. (2001). Ilköğretimde etkili öğretme ve öğrenme el kitabı- ilk okuma yazma öğretimi. Ankara: Milli Eğitim Basımevi.

WHO. (2020). Coronavirus disease (COVID-19) pandemic, 01.05 .2021 tarihinde https://www.who.int/emergencies/diseases/novel-coronavirus-2019 adresinden erişilmiştir.

Yalın, H. İ. (2009). Öğretim teknolojileri ve materyal geliştirme. Ankara: Nobel Akademik Yayıncılık.

Yeleğen, M. (1997). Illk okuma yazma öğretimi. İstanbul: İz Yayın Dağıtım.

Yıldırım, A. ve Şimşek, H. (2018). Sosyal bilimlerde nitel araştırma yöntemleri. Ankara: Seçkin Yayıncılık.

\section{Introduction}

\section{Extended Abstract}

COVID-19, called a pandemic by the World Health Organization, has caused many activities to be stopped or suspended around the world (WHO, 2020). These disruptions have also happened in the 
field of education. As in the whole world, face-to-face education was suspended in all education levels in Turkey in 2020. In Turkey, as in other countries in the world, studies on distance education have accelerated in order not to interrupt education in this process, and approximately 16 million students from pre-school to high school have started to study with distance education during the period when face-to-face education was suspended (UNESCO, 2020).

The first grade of primary school is a period in which children having completed the age of six must adapt to school and formal education and learn to read and write, so this period has a critical importance. Since first grade students and teachers have spent this critical education period with distance education during the pandemic, it is important to investigate what kind of education year they have had, to identify the problems they have encountered and to offer solutions. This study aims to determine how teaching literacy via distance education was carried out during the pandemic. We believe that this study will contribute to the planning of the education process in cases where compulsory or voluntary distance education is preferred in the future.

This study sought answers to the following research questions:

1. What are the most common problems faced by primary school first grade teachers during distance education?

2. How was teaching literacy via distance education carried out during the pandemic?

\section{Method}

In this study, the case study design, which is one of the qualitative research methods, was preferred since it was desired to examine in detail the thoughts of first grade teachers about teaching literacy via distance education, which was started to be used during the pandemic. In this study, the views of primary school first grade teachers on the process of teaching literacy via distance education were consulted and the whole process was comprehensively evaluated within the framework of teachers' views.

The study group consists of 14 volunteer first grade teachers, two teachers from each region of Turkey. One female and one male teacher from each region were included in the sample. Seven of the teachers have 0-10 years of teaching experience, five of them have 11-20 years of teaching experience, and two of them have over 20 years of teaching experience.

The data of the study were obtained through semi-structured interviews. Due to the pandemic, video calls were made with the participants over the Google Meet platform and the interviews were recorded. The interviews lasted between 30 and 40 minutes. The data of the research were analyzed using the content analysis method, and the emerging codes were derived from the data (Merriam, 2009).

\section{Results and Discussion}

Findings of the study show that although the distance education process was put into effect as a solution to prevent the interruption of education during the period when face-to-face education was suspended, it brought many problems due to the fact that neither the system nor the teachers and students who used the system were ready for this. In this study, it was observed that teachers complained that they could not receive in-service training, especially during the transition to distance education, and they were worried because they did not know how to provide education and how to use distance education platforms.

In this study, it was found that the students had problems in adapting to the distance education process, sometimes due to the unconscious behaviors of the families and sometimes due to financial inadequacies, the students did not / could not attend the distance education lessons. In parallel with previous studies, the problems expressed by teachers in this study were that students could not follow the lessons regularly due to the inadequacies in the internet and electricity infrastructure, and that the unconscious behaviors of the parents (hinting their children while reading, etc.) (Kavuk \& Demirtaş, 2021).

In this study, one of the problems that teachers focused on the most was keeping primary school first grade students in front of the screen for six lesson hours every day during the distance 
education process. The mistakes made by the children regarding the production of sounds and the spelling aspects of sounds during the literacy teaching process were other important problems that teachers pointed out. The use of videos and content on web platforms was one of the effective methods that could be preferred in learning how to pronounce and write the letter correctly in the distance education process.

Some of the teachers also stated that the EBA (Education Information Network - established by the Ministry of National Education of Turkey) content was very insufficient especially for the firstgrade level, and therefore they used supplementary web platforms. EBA content development should be accelerated and the content of EBA should be enriched at every grade level, and the content should be made attractive to children with various games and fun activities especially for primary school level.

During the literacy education given via distance education, in addition to the materials the teachers used during face-to-face education, they used educational videos, games and activities on various web platforms intensively, although those were not stated in their lesson plans. It is considered useful to use a game-based teaching model, especially in the first grade, in order to increase the motivation of children who are still at the age of play and to reinforce what they have learned.

The active role of parents in the distance education process increases the efficiency of the education that primary school students receive through distance education (Bozkurt, 2020b). Most of the teachers who participated in the study stated that the conscious parents made a great contribution to the teaching literacy process.

In this study, it was aimed to reveal the problems experienced in the distance education process and how literacy teaching was carried out via distance education within the framework of teachers' opinions. So, the findings of the study are limited to teacher opinions only. Working with other stakeholders, such as parents and students, will help to see the whole picture. Determining the views of parents on literacy education given through distance education, the information that they can give on the distance education system, the teaching methods used by teachers, and the problems children experienced in this process will help to better understand the current situation and shed light on decision-makers. Again, long-term qualitative studies with children on the effectiveness of the literacy education that children received via distance education would contribute to the literature by providing guidance on how successful the applications have been, and in which areas and what kind of deficiencies occurred in the process. 